\title{
Review \\ Catalytic Conversion of Glycerol into Hydrogen and Value-Added Chemicals: Recent Research Advances
}

\author{
Yulin $\mathrm{Hu}^{1}$, Quan $\mathrm{He}^{2} \mathbb{D}$ and Chunbao $\mathrm{Xu}^{3, *(\mathbb{D})}$ \\ 1 Faculty of Sustainable Design Engineering, University of Prince Edward Island, 550 University Ave, \\ Charlottetown, PE C1A 4P3, Canada; yulinhu@upei.ca \\ 2 Department of Engineering, Faculty of Agriculture, Dalhousie University, Truro, NS B2N 5E3, Canada; \\ quan.he@dal.ca \\ 3 Department of Chemical and Biochemical Engineering, Western University, 1151 Richmond St., \\ London, ON N6A 3K7, Canada \\ * Correspondence: cxu6@uwo.ca
}

Citation: $\mathrm{Hu}, \mathrm{Y} . ; \mathrm{He}, \mathrm{Q} . ; \mathrm{Xu}, \mathrm{C}$. Catalytic Conversion of Glycerol into Hydrogen and Value-Added Chemicals: Recent Research Advances. Catalysts 2021, 11, 1455. https://doi.org/10.3390/ catal11121455

Academic Editor: Karine De Oliveira Vigier

Received: 6 November 2021

Accepted: 24 November 2021

Published: 29 November 2021

Publisher's Note: MDPI stays neutral with regard to jurisdictional claims in published maps and institutional affiliations.

Copyright: (c) 2021 by the authors. Licensee MDPI, Basel, Switzerland. This article is an open access article distributed under the terms and conditions of the Creative Commons Attribution (CC BY) license (https:/ / creativecommons.org/licenses/by/ $4.0 /)$.

\begin{abstract}
In recent decades, the use of biomass as alternative resources to produce renewable and sustainable biofuels such as biodiesel has gained attention given the situation of the progressive exhaustion of easily accessible fossil fuels, increasing environmental concerns, and a dramatically growing global population. The conventional transesterification of edible, nonedible, or waste cooking oils to produce biodiesel is always accompanied by the formation of glycerol as the byproduct. Undeniably, it is essential to economically use this by-product to produce a range of valuable fuels and chemicals to ensure the sustainability of the transesterification process. Therefore, recently, glycerol has been used as a feedstock for the production of value-added $\mathrm{H}_{2}$ and chemicals. In this review, the recent advances in the catalytic conversion of glycerol to $\mathrm{H}_{2}$ and high-value chemicals are thoroughly discussed. Specifically, the activity, stability, and recyclability of the catalysts used in the steam reforming of glycerol for $\mathrm{H}_{2}$ production are covered. In addition, the behavior and performance of heterogeneous catalysts in terms of the roles of active metal and support toward the formation of acrolein, lactic acid, 1,3-propanediol, and 1,2-propanediol from glycerol are reviewed. Recommendations for future research and main conclusions are provided. Overall, this review offers guidance and directions for the sufficient and economical utilization of glycerol to generate fuels and high value chemicals, which will ultimately benefit industry, environment, and economy.
\end{abstract}

Keywords: glycerol; catalysts; $\mathrm{H}_{2}$; chemicals; sustainability

\section{Introduction}

Until now, considerable effort has been dedicated toward developing renewable resources to completely or partially replace with fossil fuels, including wind, solar, geothermal, nuclear, tidal power, and biomass, among which biomass is regarded as the best energy precursor, especially given the introduction of the concept of biofuels [1]. Biofuels can be categorized into solid (e.g., pellets, briquettes, and biochar), gas (e.g., biohydrogen, biogas, and biomethane), and liquid (e.g., bioethanol, biobutanol, bio-oil, and biodiesel) fuels, and they are readily distributed as energy carriers within the existing infrastructure. For example, biodiesel obtained from animal fats, vegetable oils, or waste cooking oils via transesterification (Figure 1) can be directly used in diesel engines without modification or blending with diesel fuel. Owing to the changes in the energy and environmental landscapes, stringent environmental regulations have been imposed by governments, e.g., B-5, which is composed of 5\% of biodiesel and 95\% of diesel fuel, is primarily used in Canada to reduce greenhouse gas (GHG) emissions and other toxic gas emissions caused by burning fossil fuels, which has boosted biodiesel production in recent decades [2]. Clearly, this blooming production of biodiesel results in a glut of glycerol and a huge quantity of generated waste. Approximately, for each $1000 \mathrm{~kg}$ biodiesel produced, $110 \mathrm{~kg}$ of crude glycerol 
is generated as the low-value by-product [3]. It was estimated that the global glycerol production reached approx. 4.2 million tons in 2020; however, the demand for glycerol was lower than 3.5 million tons, causing a large quantity of crude glycerol to be considered as a waste [4]. Consequently, efficient valorization technologies must be developed to convert glycerol into useful products rather than disposing them as waste. Because of its high functionalization, glycerol can be valorized into a wide range of products via multiple conversion routes, as discussed by Katryniok et al. [5]. Table 1 summarizes the high-value products, including fuels and chemicals, that can be feasibly produced from glycerol. In addition to $\mathrm{H}_{2}$ and chemicals, glycerol can be applied as feed to react with free fatty acids to form glycerides by glycerolysis (also called glycerol esterification), and the resulting glyceride can be further treated to produce biodiesel via alkaline transesterification. Nevertheless, owing to the use of high-cost metallic catalysts and higher temperature (up to $\sim 200^{\circ} \mathrm{C}$ ), glycerolysis is not a technology commonly used in the biodiesel industry, rather being widely employed in the cosmetic, pharmaceutical, and food industries to synthesize surfactants and emulsifiers [6]. The associated underlying mechanism, major reaction conditions (temperature, reactor configuration, molar ratio of glycerol and free fatty acid, type of free fatty acid, catalyst type, and glycerol purity), and technical challenges have been recently reviewed by Mamtani et al. [7] and Abomohra et al. [8].

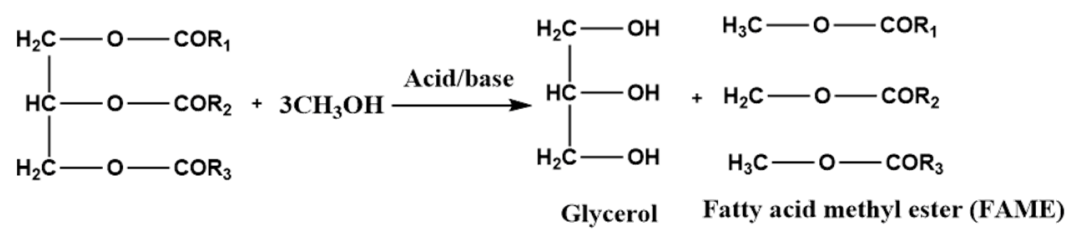

Figure 1. The chemical reaction scheme for transesterification of triglyceride fatty acid methyl ester (FAME) and glycerol as the by-product.

Table 1. Summary of value-added products obtained from glycerol by catalytic routes.

\begin{tabular}{|c|c|c|c|}
\hline Reaction & Catalyst & Product & Reference \\
\hline \multirow[t]{4}{*}{ Dehydration } & $\mathrm{MoP}$ & Acrolein & [9] \\
\hline & Mo-V / ZSM-5 & Acrylic acid & [10] \\
\hline & $\mathrm{Au}-\mathrm{Pt} / \mathrm{Al}_{2} \mathrm{O}_{3}$ & Lactic acid & [11] \\
\hline & $\mathrm{Au}-\mathrm{Pt} / \mathrm{Al}_{2} \mathrm{O}_{3}$ & Glyceric acid & [11] \\
\hline \multirow{5}{*}{ Oxidation } & $\mathrm{Cu}-\mathrm{Mg}$ & Glycolic acid & [12] \\
\hline & $\mathrm{Cu} / \mathrm{Al}_{2} \mathrm{O}_{3}$ & Oxalic acid & [13] \\
\hline & $\mathrm{CoO}_{\mathrm{x}}$ & Dihydroxyacetone & [14] \\
\hline & $\mathrm{WO}_{3} / \mathrm{TiO}_{2}$ & Glyceraldehyde & [15] \\
\hline & $\mathrm{Ru}-\mathrm{Cu} / \mathrm{CNT}$ & 1,2-Propanediol & [16] \\
\hline \multirow[t]{2}{*}{ Hydrogenolysis } & $\mathrm{Pt} / \mathrm{W}-\mathrm{MCFs}$ & 1,3-Propanediol & [17] \\
\hline & $\begin{array}{l}\mathrm{Ni} / \mathrm{WO}_{3}-\mathrm{TiO}_{2} ; \\
\mathrm{Ni} / \mathrm{WO}_{3}-\mathrm{ZrO}_{2}\end{array}$ & 1-Propanol & [18] \\
\hline Steam reforming & $\mathrm{Pt} / \mathrm{CCO}$ & $\mathrm{H}_{2}$-rich syngas & [19] \\
\hline Esterification & $\mathrm{ZrO}_{2} / \mathrm{MCM}-41$ & Glycerides & [20] \\
\hline Etherification & $\begin{array}{c}\text { Zeolites; heteropolyacids; } \\
\text { TSA/SiO } \mathrm{Si}_{2} \text { TPA/SiO } \mathrm{Si}_{2} ; \\
\mathrm{TSA} / \mathrm{MCM}-41 ; \\
\mathrm{TSA} / \mathrm{SBA}-15 ; \\
\mathrm{TPA} / \mathrm{MCM}-41 ; \\
\text { TSA/SBA-15; ion } \\
\text { exchange resins }\end{array}$ & Methyl tert-butyl ether & [21] \\
\hline Polymerization & & Polymers & [22] \\
\hline
\end{tabular}

To enhance the efficiency of the valorization routes, the role of catalysts is vital, as evidenced by a surge in the number of related publications. Unlike transesterification, where chemical routes are clear with well-established catalysts, glycerol conversion routes are broad and versatile; therefore, it is challenging to cover a vast field of the relevant 
research. Thus, in this review article, recent advances in glycerol valorization into $\mathrm{H}_{2}$ by steam reforming and various chemicals, including acrolein by dehydration, lactic acid by oxidation, and 1,2-propanediol and 1,3-propanediol by selective hydrogenolysis, are discussed. Considering the chemical structure of the glycerol molecule, the activation and reactivity of $\mathrm{C}-\mathrm{C}, \mathrm{C}-\mathrm{O}, \mathrm{C}-\mathrm{H}$, and $\mathrm{O}-\mathrm{H}$ bonds play an important role in the selection of reaction conditions and catalytic performance. For example, for $\mathrm{C}-\mathrm{C}$ and $\mathrm{C}-\mathrm{O}$ cleavage, bifunctional catalysts consisting of active metals and support are favorable for the reaction, among which a metallic complex or noble catalyst such as $\mathrm{Pt}, \mathrm{Pd}$, and $\mathrm{Rh}$ over acid catalyst support such as zeolites and activated carbon is the most common in the glycerol conversion. Conversely, in the case of $\mathrm{C}-\mathrm{H}$ and $\mathrm{O}-\mathrm{H}$ cleavage, it is critical to select a suitable metallic active center, among which noble metals and transition metals such as $\mathrm{Cu}, \mathrm{Ni}$, and Co are mainly utilized [23].

To date, most published review articles are restricted to one specific glycerol valorization technique, e.g., 1,3-propanediol by Wang et al. [24] and Eokum et al. [25]; lactic acid by Arcanjo et al. [26]; fuel additives by Smirnov et al. [27], Cornejo et al. [28], and Nanda et al. [29]; acrolein by Galadima and Muraza [30]; and $\mathrm{H}_{2}$ and syngas by He et al. [4], Lin [31], and Macedo et al. [32].On the contrary, in this review, we discuss the latest developments and advances in heterogeneous catalysts and reactor configurations for some of the most common conversion pathways including steam reforming to $\mathrm{H}_{2}$, dehydration to acrolein, oxidation to lactic acid, and selective hydrogenolysis to 1,3-propanediol and 1,2-propanediol, followed by a discussion on the directions for future research and major conclusions.

\section{Utilization of Glycerol as Feedstock to Produce $\mathbf{H}_{2}$}

$\mathrm{H}_{2}$ can act as an alternative energy carrier to replace fossil fuels and it can be produced via steam reforming of fossil fuels or biomass and water electrolysis. In industry, steam reforming of methane (SRM) for $\mathrm{H}_{2}$ production is the dominant technology, which represents around $48 \%$ of the total $\mathrm{H}_{2}$ production in the world [33]. Recent investigations regarding the glycerol conversion for producing $\mathrm{H}_{2}$ via steam reforming over a transition metal or noble metal-based catalyst are summarized in Tables 2 and 3, respectively. The underlying reaction mechanism for glycerol steam reforming was illustrated by Sahraei et al. [34], as depicted in Figure 2.

Table 2. Recent investigations on glycerol conversion for producing $\mathrm{H}_{2}$ via steam reforming over transition metal-based catalysts.

\begin{tabular}{|c|c|c|c|c|}
\hline Catalyst & Conditions & $\begin{array}{c}\text { Max. Glycerol } \\
\text { Conversion (\%) }\end{array}$ & $\begin{array}{c}\text { Max. } \mathrm{H}_{2} \\
\text { Selectivity (\%) }\end{array}$ & Reference \\
\hline $\begin{array}{l}\mathrm{Ni} / \text { upgraded slag } \\
\text { oxide }\end{array}$ & $\begin{array}{c}480{ }^{\circ} \mathrm{C} \text { and } 580{ }^{\circ} \mathrm{C} ; \\
\text { water/glycerol } \\
\text { molar ratio of } 9\end{array}$ & / & / & [35] \\
\hline $\mathrm{Ni} /$ coal fly ash & $\begin{array}{c}630^{\circ} \mathrm{C} ; \\
\text { water/glycerol } \\
\text { molar ratio of } 9 ; \\
\text { WHSV of } 6.47 \mathrm{~h}^{-1}\end{array}$ & 93 & 77 & [36] \\
\hline $\begin{array}{c}\mathrm{Ni}^{-} \\
\mathrm{MgO} / \text { attapulgite }\end{array}$ & $\begin{array}{c}400-800{ }^{\circ} \mathrm{C} ; \\
\text { steam/carbon molar } \\
\text { ratio of } 3 ; \text { WHSV of } \\
1 \mathrm{~h}^{-1}\end{array}$ & 95 & 82 & [37] \\
\hline $\begin{array}{c}\text { Single } \mathrm{Ni} / \mathrm{SiO}_{2} ; \\
\text { Single } \mathrm{CuSiO}_{2} ; \text { Dual } \\
\mathrm{Ni} / \mathrm{SiO}_{2}-\mathrm{CuSiO}_{2}\end{array}$ & $\begin{array}{l}300-600{ }^{\circ} \mathrm{C} \text {; Feed } \\
\text { rate of } 0.12 \mathrm{~mL} / \mathrm{min} \text {; } \\
\quad \text { LHSV of } 7.6 \mathrm{~h}^{-1}\end{array}$ & 100 & 80 & [38] \\
\hline $\begin{array}{c}\mathrm{Ni} / \mathrm{MCM}_{-41} ; \\
\mathrm{Ni} / \mathrm{SBA}^{-15} ; \\
\mathrm{Ni} / \mathrm{CeO}_{2}-\mathrm{MCM}_{-41} ; \\
\mathrm{Ni} / \mathrm{CeO}_{2}-\mathrm{SBA}_{-}-15\end{array}$ & $\begin{array}{c}650{ }^{\circ} \mathrm{C} ; \\
\text { steam/carbon molar } \\
\text { ratio of } 2\end{array}$ & 99 & 92 & [39] \\
\hline
\end{tabular}


Table 2. Cont.

\begin{tabular}{|c|c|c|c|c|}
\hline Catalyst & Conditions & $\begin{array}{l}\text { Max. Glycerol } \\
\text { Conversion (\%) }\end{array}$ & $\begin{array}{c}\text { Max. } \mathrm{H}_{2} \\
\text { Selectivity (\%) }\end{array}$ & Reference \\
\hline $\begin{array}{c}\mathrm{Co} / \mathrm{MgO} ; \\
\mathrm{Cu}-\mathrm{Co} / \mathrm{MgO} ; \\
\mathrm{Co} / \mathrm{MgO}-\mathrm{Al}_{2} \mathrm{O}_{3}\end{array}$ & $\begin{array}{l}500-650{ }^{\circ} \mathrm{C} \text {; WHSV } \\
\text { of } 2.88 \mathrm{~h}^{-1}\end{array}$ & 100 & 75 & [40] \\
\hline $\begin{array}{l}\mathrm{Ni} / \mathrm{La}_{2} \mathrm{O}_{3}-\mathrm{Al}_{2} \mathrm{O}_{3} \\
\mathrm{Ni} / \mathrm{CeO}_{2}-\mathrm{Al}_{2} \mathrm{O}_{3} \\
\mathrm{Ni} / \mathrm{MgO}_{2}-\mathrm{Al}_{2} \mathrm{O}_{3} \\
\mathrm{Ni} / \mathrm{CeO}_{2}-\mathrm{ZrO}_{2}\end{array}$ & $\begin{array}{c}500{ }^{\circ} \mathrm{C} \text {; glycerol } \\
\text { loading of } 20 \mathrm{wt} \% \\
\text { feed rate of } \\
0.5 \mathrm{~mL} / \mathrm{min} \text {; catalyst } \\
\text { loading of } 5 \mathrm{wt} \%\end{array}$ & 87 & 67 & [41] \\
\hline $\begin{array}{l}\mathrm{Ni} / \mathrm{amZr} ; \mathrm{Ni} / \mathrm{Zr703} \\
\mathrm{Ni} / \mathrm{Zr873} ; \mathrm{Ni} / 9 Y \mathrm{SZ}\end{array}$ & $\begin{array}{l}550{ }^{\circ} \mathrm{C} \text {; glycerol } \\
\text { loading of } 20 \mathrm{wt} \% \text {; }\end{array}$ & / & / & [42] \\
\hline $\mathrm{Co} / \mathrm{MgO}-\mathrm{Al}_{2} \mathrm{O}_{3}$ & $\begin{array}{c}500{ }^{\circ} \mathrm{C} \text {; GHSV of } \\
200,000 \mathrm{~h}^{-1} ; \\
\text { glycerol loading of } \\
20 \mathrm{vol} \%\end{array}$ & 65 & 37 & [43] \\
\hline $\begin{array}{c}\mathrm{Ni} / \mathrm{SBA}-15 ; \\
\mathrm{Ni} / \mathrm{La}_{2} \mathrm{O}_{3}-\mathrm{SBA} 15 ; \\
\mathrm{Ni} / \mathrm{La}_{2} \mathrm{O}_{3}-\mathrm{CeO}_{2-} \\
\mathrm{SBA} 15 ; \\
\mathrm{Ni} / \mathrm{La}_{2} \mathrm{O}_{3}-\mathrm{CeO}_{2-} \\
\mathrm{KIT}-6\end{array}$ & $\begin{array}{c}650^{\circ} \mathrm{C} ; \text { LHSV of } \\
2.8-11.3 \mathrm{~h}^{-1}\end{array}$ & / & 62 & [44] \\
\hline $\mathrm{Ni} / \mathrm{Mg}-\mathrm{Al}$ & $\begin{array}{c}400-700{ }^{\circ} \mathrm{C} ; \\
\text { water } / \text { glycerol } \\
\text { molar ratio of } 9 ; \text { feed } \\
\text { rate of } \\
0.025 \mathrm{~mL} / \mathrm{min}\end{array}$ & 30 & / & [45] \\
\hline $\mathrm{Ni}-\mathrm{Co} / \mathrm{CNT}$ & $\begin{array}{c}525{ }^{\circ} \mathrm{C} \text {; glycerol } \\
\text { loading of } 10 \mathrm{wt} \% \\
\text { feed rate of } \\
6.0 \mathrm{~mL} / \mathrm{min}\end{array}$ & 96 & 94 & [46] \\
\hline
\end{tabular}

Table 3. Recent investigations on glycerol conversion for producing $\mathrm{H}_{2}$ via steam reforming over noble-based catalysts.

\begin{tabular}{|c|c|c|c|c|}
\hline Catalyst & Conditions & $\begin{array}{c}\text { Max. Glycerol } \\
\text { Conversion (\%) }\end{array}$ & $\begin{array}{c}\text { Max. } \mathrm{H}_{2} \\
\text { Selectivity (\%) }\end{array}$ & Reference \\
\hline $\mathrm{Pt}-\mathrm{Ni} / \mathrm{MgAl}_{2} \mathrm{O}_{4}$ & $\begin{array}{c}700-850{ }^{\circ} \mathrm{C} ; \\
\text { Water/glycerol } \\
\text { molar ratio of } 12\end{array}$ & 100 & / & [47] \\
\hline $\begin{array}{l}\mathrm{Rh} / \mathrm{CeO}_{2}-\mathrm{Al}_{2} \mathrm{O}_{3} ; \\
\mathrm{Rh} / \mathrm{MgO}-\mathrm{Al}_{2} \mathrm{O}_{3} ; \\
\mathrm{Rh} / \mathrm{La}_{2} \mathrm{O}_{3}-\mathrm{Al}_{2} \mathrm{O}_{3}\end{array}$ & $\begin{array}{c}400-750{ }^{\circ} \mathrm{C} \text {; glycerol } \\
\text { loading of } 20 \mathrm{vol} \% \text {; } \\
\text { feed rate of } \\
0.12 \mathrm{NmL} / \mathrm{min} ; \\
\mathrm{WHSV} \text { of } \\
50,000 \mathrm{NmL} / \mathrm{g} \cdot \mathrm{h}\end{array}$ & 90 & 78 & [48] \\
\hline $\begin{array}{l}\mathrm{Pd} / \mathrm{CeO}_{2}-\mathrm{Al}_{2} \mathrm{O}_{3} \\
\mathrm{Pt} / \mathrm{CeO}_{2}-\mathrm{Al}_{2} \mathrm{O}_{3}\end{array}$ & $\begin{array}{c}400-750{ }^{\circ} \mathrm{C} ; \\
\text { water/glycerol } \\
\text { molar ratio of } 20\end{array}$ & 95 & 94 & [49] \\
\hline $\begin{array}{c}\mathrm{Pt} / \mathrm{SiO}_{2}-\mathrm{C} ; \mathrm{Pt} / \mathrm{SiO}_{2} \\
\mathrm{Pt} / \mathrm{C}\end{array}$ & $\begin{array}{c}450{ }^{\circ} \mathrm{C} \text {; glycerol } \\
\text { loading of } \\
10-50 \mathrm{wt} \% \text {; } \\
\text { steam/carbon molar } \\
\text { ratio of } 1.6-15 ; \\
\text { WHSV of } \\
2.9-25.7 \mathrm{~h}^{-1}\end{array}$ & 100 & 75 & [50] \\
\hline
\end{tabular}


Table 3. Cont.

\begin{tabular}{|c|c|c|c|c|}
\hline Catalyst & Conditions & $\begin{array}{c}\text { Max. Glycerol } \\
\text { Conversion (\%) }\end{array}$ & $\begin{array}{c}\text { Max. } \mathrm{H}_{2} \\
\text { Selectivity (\%) }\end{array}$ & Reference \\
\hline $\begin{array}{l}\mathrm{Rh} / \mathrm{MgO}-\mathrm{Al}_{2} \mathrm{O}_{3} \\
\mathrm{Ru} / \mathrm{MgO}-\mathrm{Al}_{2} \mathrm{O}_{3} \\
\mathrm{Pt} / \mathrm{MgO}-\mathrm{Al}_{2} \mathrm{O}_{3}\end{array}$ & $\begin{array}{c}300-600{ }^{\circ} \mathrm{C} ; \\
\text { water } / \text { glycerol } \\
\text { molar ratio of } 9 ; \\
\text { GHSV of } \\
35,000 \mathrm{~mL} / \mathrm{g} \cdot \mathrm{h}\end{array}$ & 100 & 100 & [51] \\
\hline $\mathrm{Pt}-\mathrm{Sn} / \mathrm{C}$ & $\begin{array}{l}350-400{ }^{\circ} \mathrm{C} \text {; feed } \\
\text { rate of } 0.05 \mathrm{~mL} / \mathrm{min} \text {; } \\
\text { glycerol loading of } \\
10-30 \mathrm{wt} \% \\
400{ }^{\circ} \mathrm{C} \cdot \text { feed rate of }\end{array}$ & 100 & 45 & [52] \\
\hline $\mathrm{Pt} / \mathrm{VO}_{\mathrm{x}}-\mathrm{Al}_{2} \mathrm{O}_{3}$ & $\begin{array}{l}1.9 \mathrm{~mL} / \mathrm{h} \text {; glycerol } \\
\text { loading of } 3.3 \mathrm{~mol} / \mathrm{h}\end{array}$ & / & / & [53] \\
\hline $\mathrm{Pt} / \mathrm{SiO}_{2}$ & $\begin{array}{c}300-400^{\circ} \mathrm{C} \text {; feed } \\
\text { rate of } 3-7 \mathrm{~mL} / \mathrm{h} ; \\
\mathrm{WHSV} \text { of } \\
47.25-110.25 \mathrm{~h}^{-1} ; \\
\text { steam/carbon molar } \\
\text { ratio of } 3\end{array}$ & 97 & 97 & [54] \\
\hline $\mathrm{Ru} /$ upgraded slag & $630^{\circ} \mathrm{C}$ & & & \\
\hline $\begin{array}{l}\text { oxide metallurgical } \\
\text { waste; }\end{array}$ & $\begin{array}{l}\text { Water/glycerol ratio } \\
\text { of 9; feed rate of }\end{array}$ & 100 & 78 & [55] \\
\hline $\begin{array}{l}\mathrm{Rh} / \text { upgraded slag } \\
\text { oxide metallurgical } \\
\text { waste }\end{array}$ & $\begin{array}{l}0.05 \mathrm{~mL} / \mathrm{min} ; \mathrm{GHSV} \\
\text { of } \\
10,966 \mathrm{~cm}^{3} / \mathrm{g}_{\text {cat }}-1 \mathrm{~h}^{-1}\end{array}$ & & & \\
\hline $\mathrm{Rh} / \mathrm{Al}_{2} \mathrm{O}_{3}$ & $400^{\circ} \mathrm{C}$ & 99 & / & [56] \\
\hline $\mathrm{Ru}-\mathrm{Ni} / \mathrm{CeO}_{2}-\mathrm{Al}_{2} \mathrm{O}_{3}$ & $\begin{array}{c}550-800{ }^{\circ} \mathrm{C} \text {; WHSV } \\
\text { of } \mathrm{h}^{-1}\end{array}$ & / & 89 & [57] \\
\hline $\mathrm{Rh} / \mathrm{MgAl}_{2} \mathrm{O}_{4}$ & $\begin{array}{c}300-600{ }^{\circ} \mathrm{C} ; \\
\text { water/glycerol ratio } \\
\text { of } 3-9 ; 35,000- \\
70,000 \mathrm{~mL} \cdot \mathrm{g}^{-1} \cdot \mathrm{h}^{-1}\end{array}$ & $>99$ & 75 & [58] \\
\hline
\end{tabular}

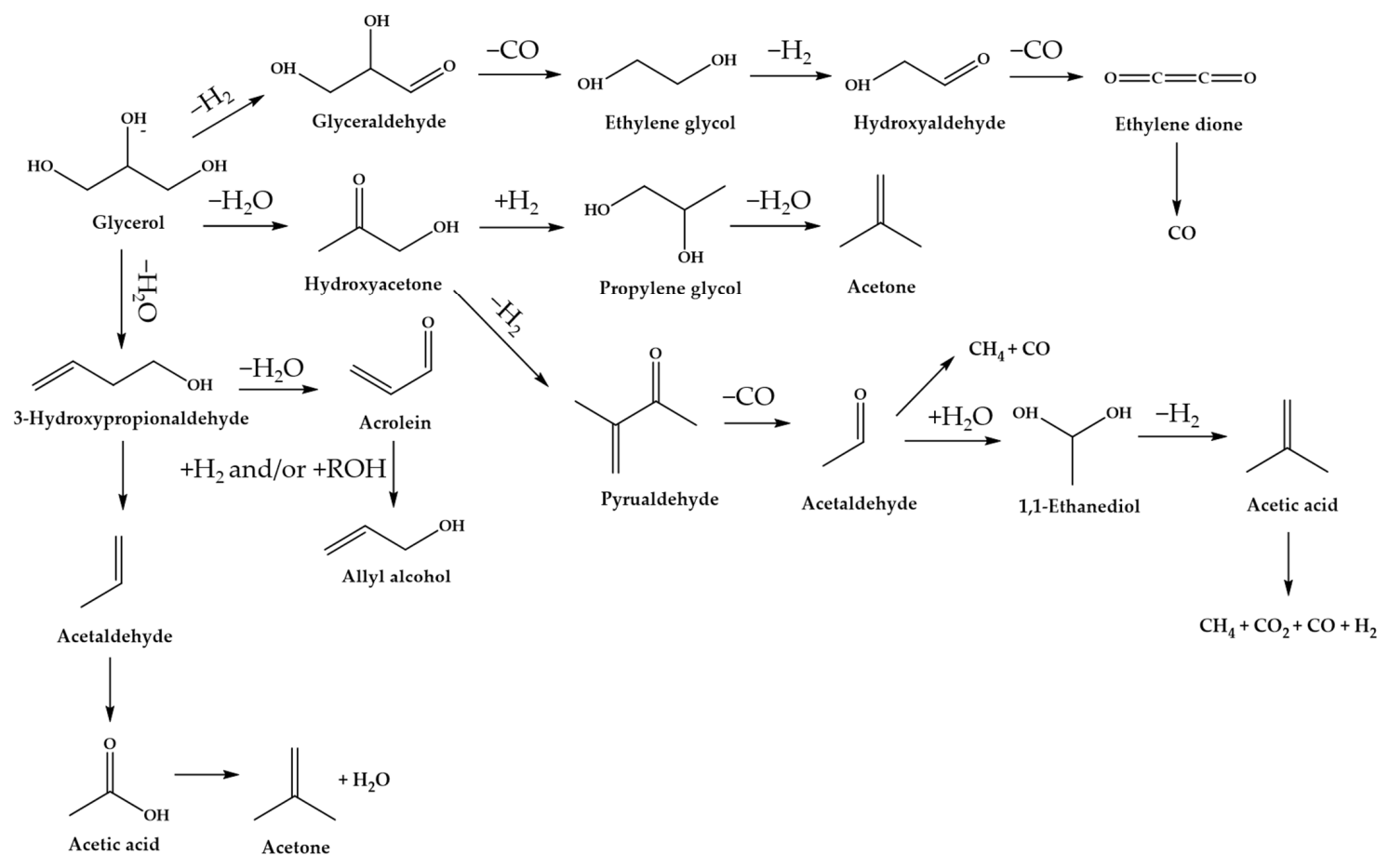

Figure 2. The reaction mechanism for steam reforming of glycerol [34]. 
Steam reforming is regarded as the most promising approach to produce $\mathrm{H}_{2}$ from glycerol, and the reactions involved are shown below:

$$
\begin{aligned}
& \text { Overall reaction: } \mathrm{C}_{3} \mathrm{H}_{8} \mathrm{O}_{3}+3 \mathrm{H}_{2} \mathrm{O} \rightarrow 7 \mathrm{H}_{2}+3 \mathrm{CO}_{2} \\
& \text { +Glycerol decomposition: } \mathrm{C}_{3} \mathrm{H}_{8} \mathrm{O}_{3} \rightarrow 3 \mathrm{CO}+4 \mathrm{H}_{2} \\
& \text { Water-gas shift reaction: } \mathrm{CO}+\mathrm{H}_{2} \mathrm{O} \leftrightarrow \mathrm{H}_{2}+\mathrm{CO}_{2}
\end{aligned}
$$

Theoretically, one mole of glycerol can lead to the formation of seven moles of $\mathrm{H}_{2}$; whereas the occurrence of side reactions such as methanation of $\mathrm{CO}$ (Equation (4)) and $\mathrm{CO}_{2}$ (Equation (5)) demonstrates a negative impact on $\mathrm{H}_{2}$ yield.

$$
\begin{gathered}
\mathrm{CO}+3 \mathrm{H}_{2} \rightleftharpoons \mathrm{CH}_{4}+\mathrm{H}_{2} \mathrm{O} \\
\mathrm{CO}_{2}+4 \mathrm{H}_{2} \rightleftharpoons \mathrm{CH}_{4}+2 \mathrm{H}_{2} \mathrm{O}
\end{gathered}
$$

In addition to the methanation of $\mathrm{CO}$ and $\mathrm{CO}_{2}$, a series of other side reactions might also occur, such as dry reforming of $\mathrm{CH}_{4}$ (Equation (6)), steam reforming of $\mathrm{CH}_{4}$ (Equation (7)), hydrogenolysis of glycerol (Equation (8)), the Boudouard reaction (Equation (9)), methane cracking (Equation (10)), and reduction of $\mathrm{CO}$ (Equation (11)) and $\mathrm{CO}_{2}$ (Equation (12)).

$$
\begin{gathered}
\mathrm{CH}_{4}+\mathrm{CO}_{2} \rightleftharpoons 2 \mathrm{CO}+2 \mathrm{H}_{2} \\
\mathrm{CH}_{4}+\mathrm{H}_{2} \mathrm{O} \rightleftharpoons \mathrm{CO}+3 \mathrm{H}_{2} \\
\mathrm{C}_{3} \mathrm{H}_{8} \mathrm{O}_{3}+2 \mathrm{H}_{2} \rightleftharpoons 2 \mathrm{CH}_{4}+\mathrm{CO}+2 \mathrm{H}_{2} \mathrm{O} \\
2 \mathrm{CO} \rightleftharpoons \mathrm{CO}_{2}+\mathrm{C} \\
\mathrm{CH}_{4} \rightarrow 2 \mathrm{H}_{2}+\mathrm{C} \\
\mathrm{CO}+\mathrm{H}_{2} \rightarrow \mathrm{H}_{2} \mathrm{O}+\mathrm{C} \\
\mathrm{CO}_{2}+\mathrm{H}_{2} \rightarrow 2 \mathrm{H}_{2} \mathrm{O}+\mathrm{C}
\end{gathered}
$$

\subsection{Transition Metals}

To improve $\mathrm{H}_{2}$ yield, a range of catalysts have been applied in the steam reforming of glycerol. In general, owing to their low price and wide availability, transition metals (i.e., $\mathrm{Ni}$ and $\mathrm{Co}$ )-based catalysts have been extensively investigated. On the industrial scale, $\mathrm{Ni}$ is most commonly used in steam reforming because of its superior catalytic performance, superior intrinsic activity, and ease of dispersal over the catalyst support. In a previous study, Charisiou et al. [59] conducted glycerol steam reforming over $\mathrm{Ni} / \mathrm{Al}_{2} \mathrm{O}_{3}$, $\mathrm{Ni} / \mathrm{ZrO}_{2}$, and $\mathrm{Ni} / \mathrm{SiO}_{2}$ at $400-750{ }^{\circ} \mathrm{C}$, and $\mathrm{Ni} / \mathrm{SiO}_{2}$ was identified as the best catalyst for $\mathrm{H}_{2}$ production and demonstrated the highest level of catalytic stability. Karakoc et al. [60] also employed various $\mathrm{Ni}$-based catalysts (i.e., $\mathrm{Ni} / \mathrm{Al}_{2} \mathrm{O}_{3}, \mathrm{Ni} / \mathrm{SiO}_{2}$, and $\mathrm{Ni} / \mathrm{CeO}_{2}$ ) in glycerol steam reforming to produce $\mathrm{H}_{2}$, and the highest $\mathrm{H}_{2}$ yield of $4.82 \mathrm{~mol} / \mathrm{mol}_{\text {glycerol }}$ was attained at $650{ }^{\circ} \mathrm{C}$, a Ni loading of $15 \mathrm{wt} \%$, and water-to-glycerol ratio of 15 . However, the deactivation of Ni-based catalysts is normally observed due to sintering and coke deposition. One solution to tackle this challenge is to integrate $\mathrm{Ni}$ with other transition metals such as $\mathrm{Cu}$ and $\mathrm{Co}$. A positive synergistic effect is expected to exist between $\mathrm{Ni}$ and $\mathrm{Cu}$ or $\mathrm{Co}$, which could be related to the formation of $\mathrm{Ni}-\mathrm{Cu}$ or Ni-Co alloys. This formed $\mathrm{Ni}-\mathrm{Cu}$ or Ni-Co alloy helps to modify Ni nanoparticles either geometrically or electronically through the formation of small ensembles of $\mathrm{Ni}$ sites, where the strong catalytic activity of $\mathrm{Ni}$ for $\mathrm{C}-\mathrm{C}$ bond cleavage is maintained and coke deposition and methanation are restrained [61,62]. Additionally, the existence of Ni-Cu or Ni-Co alloys is beneficial to retarding Ni sintering when considering the relatively lower Tammann temperature of $\mathrm{Ni}$ (i.e., $590{ }^{\circ} \mathrm{C}$ ) than the common operating temperature in steam reforming [63]. As illustrated in Figure 3, $\mathrm{Cu}$ is beneficial to the water-gas shift reaction, and Ni promotes 
the cleavage of $\mathrm{C}-\mathrm{C}$ bonds of glycerol. The hydroxyl free radicals present in the solution together with the released carbonyl radicals from the decarbonylation of glycerol can be easily absorbed by the surface of the catalyst, and thus positively proceed the water gas shift reaction [64]. Co was also utilized by Sanchez and Comelli [65] to prepare $\mathrm{Ni}-\mathrm{Co} / \mathrm{Al}_{2} \mathrm{O}_{3}$ bimetallic catalysts used in the steam reforming of glycerol to enhance $\mathrm{H}_{2}$ production. In addition to promoting $\mathrm{H}_{2}$ formation, $\mathrm{Co}$ addition is able to minimize coke formation since it offers high oxygen affinity and, hence, facilitates the sorption of oxygen species in Ni-Co. Another solution for ensuring low coke deposition and promoting $\mathrm{H}_{2}$ production is to modify Ni-based catalysts with metal oxide promoters with redox and basic properties such as $\mathrm{MgO}$ and $\mathrm{La}_{2} \mathrm{O}_{3}$ [62]. Sánchez et al. [66] studied the catalytic performance of $\mathrm{Ni}$ supported on La-modified $\mathrm{Al}_{2} \mathrm{O}_{3}$ in $\mathrm{H}_{2}$ production via glycerol steam reforming, and compared the performance with $\mathrm{Ni} / \mathrm{Al}_{2} \mathrm{O}_{3}$ and $\mathrm{La}_{2} \mathrm{O}_{3} / \mathrm{Al}_{2} \mathrm{O}_{3}$. They observed that the catalyst support modified by La provided higher surface area and lower carbon deposition, thereby ensuring higher stability of $\mathrm{Ni} / \mathrm{La}_{2} \mathrm{O}_{3}-\mathrm{Al}_{2} \mathrm{O}_{3}$ in the reaction. Charisiou et al. [67] modified $\mathrm{Al}_{2} \mathrm{O}_{3}$ supported by $\mathrm{CaO}-\mathrm{MgO}$, and a highly selective and stable catalyst, i.e., $\mathrm{Ni} / \mathrm{CaO}-\mathrm{MgO}-\mathrm{Al}_{2} \mathrm{O}_{3}$, was synthesized; this newly developed catalyst exhibited smaller $\mathrm{Ni}$ species crystalline size, higher basicity, and increased surface amount of $\mathrm{Ni}^{0}$ phase, which, in turn, promoted the water gas shift reaction to form $\mathrm{H}_{2}$ and $\mathrm{CO}_{2}$ and retarded $\mathrm{CO}$ production. In addition, the use of $\mathrm{CaO}-\mathrm{MgO}$ as a modifier was not only advantageous for minimizing the carbon deposition on the surface of the catalyst but also altering the structure of the carbon to become less graphitic and more defective.

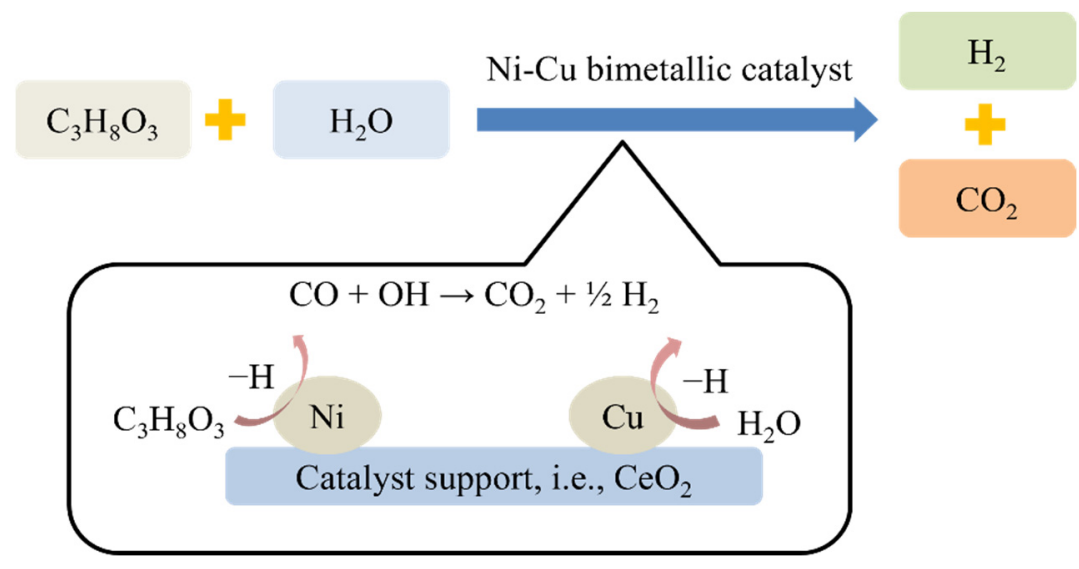

Figure 3. The underlying mechanism of $\mathrm{Ni}-\mathrm{Cu} / \mathrm{CeO}_{2}$ in the steam reforming of glycerol [64].

$\mathrm{Co}$, as another transition metal, has also been broadly used in the steam reforming of glycerol for $\mathrm{H}_{2}$ production. Similar to Ni-based catalysts, Co-based catalysts also suffer from metal sintering, coke deposition, and catalyst deactivation. Dobosz et al. [68] applied $\mathrm{Co} / \mathrm{Ca}_{10}\left(\mathrm{PO}_{4}\right)_{6}(\mathrm{OH})_{2}$ and $\mathrm{Co}-\mathrm{Ce} / \mathrm{Ca}_{10}\left(\mathrm{PO}_{4}\right)_{6}(\mathrm{OH})_{2}$ in glycerol steam reforming to produce $\mathrm{H}_{2}$, and the incorporation of $\mathrm{CeO}_{2}$ effectively prevented Co sintering, thus leading to a relatively higher catalyst stability and $\mathrm{H}_{2}$ selectivity than $\mathrm{Co} / \mathrm{Ca}_{10}\left(\mathrm{PO}_{4}\right)_{6}(\mathrm{OH})_{2}$. Adding $\mathrm{Cu}$ to the Co-based catalyst to suppress carbon deposition was investigated by Moogi et al. [40]. Based on the results from $\mathrm{H}_{2}-\mathrm{TPR}$ analysis, the recyclability of the Cobased catalyst was enhanced in the presence of $\mathrm{Cu}$, and a shift in the reduction profile toward a lower temperature was achieved. As a comparison, $5 \mathrm{wt} \% \mathrm{Cu}-20 \mathrm{wt} \% \mathrm{Co} / \mathrm{MgO}$ led to complete glycerol conversion and the highest $\mathrm{H}_{2}$ yield of $74.6 \%$, which could be due to the smaller particle size and higher surface area and metal dispersion. They found that an acceptable catalytic activity of $\mathrm{Cu}$ modified catalyst was attained up to $30 \mathrm{~h}$ of reaction by limiting carbon formation. Menezes et al. [69] synthesized Co catalysts by the wet impregnation preparation method using three different catalyst supports: $\mathrm{Al}_{2} \mathrm{O}_{3}, \mathrm{Nb}_{2} \mathrm{O}_{5}$, and $\mathrm{Al}_{2} \mathrm{O}_{3}-\mathrm{Nb}_{2} \mathrm{O}_{5}$. Their catalytic performance in the glycerol steam reforming at $500{ }^{\circ} \mathrm{C}$ for $30 \mathrm{~h}, 20 \mathrm{vol} \%$ of glycerol loading, and GHSV of $200,000 \mathrm{~h}^{-1}$ was assessed. As expected, $\mathrm{Co} / \mathrm{Al}_{2} \mathrm{O}_{3}-\mathrm{Nb}_{2} \mathrm{O}_{5}$ was identified as the best catalyst with respect to the highest glycerol 
conversion of $90 \%$ and $\mathrm{H}_{2}$ yield of $65 \%$ at $8 \mathrm{~h}$ of reaction; however, coke formed in all tested catalysts after $24 \mathrm{~h}$ of reaction. In addition to $\mathrm{Nb}_{2} \mathrm{O}_{5}$, the effect of the incorporation of $\mathrm{MgO}$ with the Co-based catalysts on the catalytic acidity, reducibility, and cobalt dispersion was also evaluated by Menezes et al. [43]. Despite the use of $\mathrm{Co} / \mathrm{MgO}-\mathrm{Al}_{2} \mathrm{O}_{3}$ resulting in a higher glycerol conversion and $\mathrm{H}_{2}$ yield, the nature of coke formed during the reaction was altered toward a filamentous rather than an amorphous structure.

\subsection{Noble Metals}

Compared to transition-metal-based catalysts, the catalysts based on noble metals (e.g., $\mathrm{Rh}, \mathrm{Ru}, \mathrm{Pt}$, and $\mathrm{Pd}$ ) are more stable and active in the steam reforming of glycerol for producing $\mathrm{H}_{2}$. Together with $\mathrm{Ni}$, $\mathrm{Ru}$ and $\mathrm{Pt}$ are regarded as the most promising metals in the steam reforming of glycerol for enhancing $\mathrm{H}_{2}$ production. Until now, the catalytic activity, stability, and reducibility of Pt-based catalysts in glycerol steam reforming, such as $\mathrm{Pt}$ $\mathrm{Ni} / \mathrm{MgAl}_{2} \mathrm{O}_{4}$ [47], Pt/ $\mathrm{CeO}_{2}-\mathrm{Al}_{2} \mathrm{O}_{3}$ [49], Pt/SiO $2-\mathrm{C}$ [50], Pt-Sn/C [52], and Pt-Mn/AC [70] have been substantially explored owing to their excellent selectivity toward $\mathrm{C}-\mathrm{C}$ bond cleavage. The superior catalysts utilized in the glycerol steam reforming should meet certain criteria including (i) an appropriate interaction between metal and support to ensure excellent stability and reproducibility during the reaction; (ii) high metal dispersion; and (iii) resistance to carbon deposition and sintering. Therefore, the selection of a proper support that can enhance the dispersion of active metal particles and the interaction with metal plays an important role in determining catalytic performance [32]. Recently, Buffoni et al. [50] examined the effects of catalyst support (i.e., $\mathrm{C}, \mathrm{SiO}_{2}$, and $\mathrm{SiO}_{2}-\mathrm{C}$ ) on the steam reforming of glycerol over Pt-based catalysts at $450{ }^{\circ} \mathrm{C}$ with respect to catalytic activity and stability. Unlike conventional oxides supports such as $\mathrm{SiO}_{2}$ and $\mathrm{Al}_{2} \mathrm{O}_{3}$ that offer good metal-support interaction, the adoption of activated carbon as the catalyst support exhibited a high surface area, surface-enriched functional groups, and ease in metal recovery. The results suggested that $\mathrm{Pt} / \mathrm{SiO}_{2}-\mathrm{C}$ and $\mathrm{Pt} / \mathrm{C}$ led to a higher glycerol conversion of $83 \%$ and $85 \%$, respectively, and to a $\mathrm{H}_{2}$ selectivity of $51 \%$ and $52 \%$, respectively, than those obtained using $\mathrm{Pt} / \mathrm{SiO}_{2}$ (glycerol conversion of $64 \%$ and $\mathrm{H}_{2}$ selectivity of $38.8 \%$ ), due to the lowest metallic dispersion observed in the presence of $\mathrm{Pt} / \mathrm{SiO}_{2}$. In terms of catalytic stability, $\mathrm{Pt} / \mathrm{SiO}_{2}-\mathrm{C}$ was identified as the most stable catalyst over $66 \mathrm{~h}$ on stream, during which only $10 \%$ of its original catalytic activity was lost after the reaction, which is attributed to the better interaction between $\mathrm{Pt}$ and $\mathrm{SiO}_{2}-\mathrm{C}$, which thus ensures its high resistance to metal sintering. In addition to the ability to avoid sintering, the use of $\mathrm{SiO}_{2}-\mathrm{C}$ as the support was capable of deterring coke formation induced by dehydration and condensation due to the lack of strong acid sites on the surface. In another study, Manfro et al. [71] prepared $\mathrm{Ni}$ catalysts supported on $\mathrm{Al}_{2} \mathrm{O}_{3}, \mathrm{CeO}_{2}$, and $\mathrm{ZrO}_{2}$, which were employed in $\mathrm{H}_{2}$ production from glycerol by steam reforming. The resulting $\mathrm{H}_{2}$ selectivity in decreasing order was as follows: $\mathrm{ZrO}_{2}>\mathrm{Al}_{2} \mathrm{O}_{3} \approx \mathrm{CeO}_{2}$. In addition to the use of various supports, adding promoters can further improve the performance of Pt-based catalysts in glycerol steam reforming. Pastor-Pérez and Sepúlveda-Escribano [52] used Sn as the promoter in the preparation of the Pt-based catalysts; the influence of Sn addition on the activity, $\mathrm{H}_{2}$ selectivity, and stability in the glycerol steam reforming was investigated. As suggested by XPS and TPR- $\mathrm{H}_{2}$ analyses, the interaction between $\mathrm{Sn}$ and Pt was strong and demonstrated close proximity. TEM analysis indicated that the degree of metal particle agglomerations that occurred in the bimetallic catalysts was lower than in the catalyst without adding Sn. It was also found that an increase in the Sn amount in the catalyst synthesis led to less-evident particle agglomeration. Consequently, better catalytic performance in terms of $\mathrm{H}_{2}$ selectivity and stability was attained using bimetallic catalysts, i.e., $\mathrm{Pt}-\mathrm{Sn} / \mathrm{C}$, compared with a monometallic $\mathrm{Pt} / \mathrm{C}$ catalyst. The higher $\mathrm{H}_{2}$ selectivity obtained using $\mathrm{Pt}-\mathrm{Sn} / \mathrm{C}$ was due to the promoted $\mathrm{CO}$ oxidation to form $\mathrm{H}_{2}$ in the presence of Sn. Furthermore, Sn was found to deter coke deposition and inhibit sintering, thereby enhancing catalytic stability during glycerol steam reforming. 
In addition to Pt-based catalysts, $\mathrm{Ru}-, \mathrm{Rh}-$, and Pd-based catalysts are exceptional catalysts for the steam reforming of glycerol for $\mathrm{H}_{2}$ production owing to their excellent catalytic performance and physicochemical characteristics, and their outstanding ability to deter coke deposition [32]. Senseni et al. [51] prepared different noble-based catalysts including $\mathrm{Rh} / \mathrm{MgO}-\mathrm{Al}_{2} \mathrm{O}_{3}, \mathrm{Ru} / \mathrm{MgO}-\mathrm{Al}_{2} \mathrm{O}_{3}$, and $\mathrm{Pt} / \mathrm{MgO}-\mathrm{Al}_{2} \mathrm{O}_{3}$ by wet impregnation, and observed that $\mathrm{Rh} / \mathrm{MgO}-\mathrm{Al}_{2} \mathrm{O}_{3}$ demonstrated the highest glycerol conversion and $\mathrm{H}_{2}$ selectivity at $300-600{ }^{\circ} \mathrm{C}$, a water-to-glycerol ratio of nine, and a GHSV of $35,000 \mathrm{~mL} \cdot \mathrm{g}^{-1} \cdot \mathrm{h}^{-1}$. Additionally, the stability assessment showed that $\mathrm{Rh} / \mathrm{MgO}-\mathrm{Al}_{2} \mathrm{O}_{3}$ was the most stable catalyst for $20 \mathrm{~h}$ under time-on-stream by offering strong resistance to carbon deposition. Owing to their excellent catalytic activity for disrupting C-C bonds and suppressing carbon deposition, Rh-based catalysts have been employed in the steam reforming of glycerol [72]. Charisiou et al. [48] investigated the activity of $\mathrm{Rh} / \mathrm{Al}_{2} \mathrm{O}_{3}, \mathrm{Rh} / \mathrm{CeO}_{2}-\mathrm{Al}_{2} \mathrm{O}_{3}$, $\mathrm{Rh} / \mathrm{MgO}-\mathrm{Al}_{2} \mathrm{O}_{3}$, and $\mathrm{Rh} / \mathrm{La}_{2} \mathrm{O}_{3}-\mathrm{Al}_{2} \mathrm{O}_{3}$ in glycerol steam reforming at $400-750{ }^{\circ} \mathrm{C}$, at a water-to-glycerol molar ratio of 20 , and a WHSV of $50,000 \mathrm{~mL} \cdot \mathrm{g}^{-1} \cdot \mathrm{h}^{-1} \cdot \mathrm{Rh} / \mathrm{Al}_{2} \mathrm{O}_{3}$ demonstrated the highest selectivity toward gas production and $\mathrm{H}_{2}$ yield at temperatures above $550{ }^{\circ} \mathrm{C}$; in contrast, $\mathrm{Rh} / \mathrm{MgO}-\mathrm{Al}_{2} \mathrm{O}_{3}$ was the least selective catalyst. When analyzing the chemical composition of liquid effluents, it was found that the order to stop the formation of liquid effluents was: $\mathrm{Rh} / \mathrm{Al}_{2} \mathrm{O}_{3}$ at $550{ }^{\circ} \mathrm{C}>\mathrm{Rh} / \mathrm{La}_{2} \mathrm{O}_{3}-\mathrm{Al}_{2} \mathrm{O}_{3}$ at $600{ }^{\circ} \mathrm{C}>\mathrm{Rh} / \mathrm{CeO}_{2}-\mathrm{Al}_{2} \mathrm{O}_{3}$ at $700{ }^{\circ} \mathrm{C} \approx \mathrm{Rh} / \mathrm{MgO}-\mathrm{Al}_{2} \mathrm{O}_{3}$ at $700{ }^{\circ} \mathrm{C}$. During $12 \mathrm{~h}$ time-on-stream, the carbon deposited on the spent catalyst was amorphous and thus sintering was avoided, suggesting high catalytic stability during steam reforming of glycerol.

\subsection{New Developments}

\subsubsection{Sorption-Enhanced Steam Reforming}

As illustrated in Equation (1), a large quantity of $\mathrm{CO}_{2}$ is generated as the by-product of glycerol steam reforming; thus, it is preferable to remove $\mathrm{CO}_{2}$ in situ and, accordingly, shift the reaction toward $\mathrm{H}_{2}$ formation based on Le Châtelier's Principle [48]. Thus, in order to achieve a carbon-neutral $\mathrm{H}_{2}$ production process, a solid $\mathrm{CO}_{2}$ sorbent such as $\mathrm{CaO}$ was introduced to the steam reforming process (also called sorption-enhanced steam reforming (SESR)), and the main reaction involved is: $\mathrm{C}_{3} \mathrm{H}_{8} \mathrm{O}_{3}(\mathrm{~g})+3 \mathrm{H}_{2} \mathrm{O}(\mathrm{g})+3 \mathrm{CaO}(\mathrm{s}) \rightarrow 3 \mathrm{CaCO}_{3}$ (s) $+7 \mathrm{H}_{2}(\mathrm{~g})$. SESR is a simple process that often leads to a high overall efficiency as production and separation are carried out simultaneously. To ensure high performance, the development of bifunctional catalysts that integrate the catalytic activity for $\mathrm{H}_{2}$ production and $\mathrm{CO}_{2}$ capture is a necessity [73]. Dang et al. [74] prepared a porous $\mathrm{Ni}-\mathrm{CaO}-\mathrm{Ca}_{12} \mathrm{Al}_{14} \mathrm{O}_{33}$ bi-functional catalyst for the SESR of glycerol, and found that the $\mathrm{H}_{2}$ purity was retained above $98 \%$, with only $30 \%$ loss in the $\mathrm{CO}_{2}$ sorption after 35 cycles of SESR-decarbonation. Surprisingly, the authors reported an innovative catalyst preparation method using organic molecule-intercalated layered double hydroxide (LDH) as the precursor, and the carbon species formed in situ from citrate during the calcination in an inert condition, which served as a template and a physical dispersant to deter particle aggregation (Figure 4). In addition, several bifunctional catalysts have been synthesized and tested in the SESR of glycerol to optimize $\mathrm{H}_{2}$ production and reduce $\mathrm{CO}_{2}$ formation [75,76]. In addition to CaO-based sorbents for improving $\mathrm{H}_{2}$ production from glycerol via SESR, a range of sorbents derived from hydrotalcite, $\mathrm{Mg}$-based double salts, and alkali metal-based oxides (e.g., $\mathrm{Li}_{4} \mathrm{SiO}_{4}$, $\mathrm{Li}_{2} \mathrm{ZrO}_{3}$, and $\mathrm{Na}_{2} \mathrm{ZrO}_{3}$ ) have demonstrated positive impacts on $\mathrm{H}_{2}$ production in the water gas shift reaction and steam reforming of methane [77,78]; however, so far, no study has evaluated their effectiveness in the SESR of glycerol. 

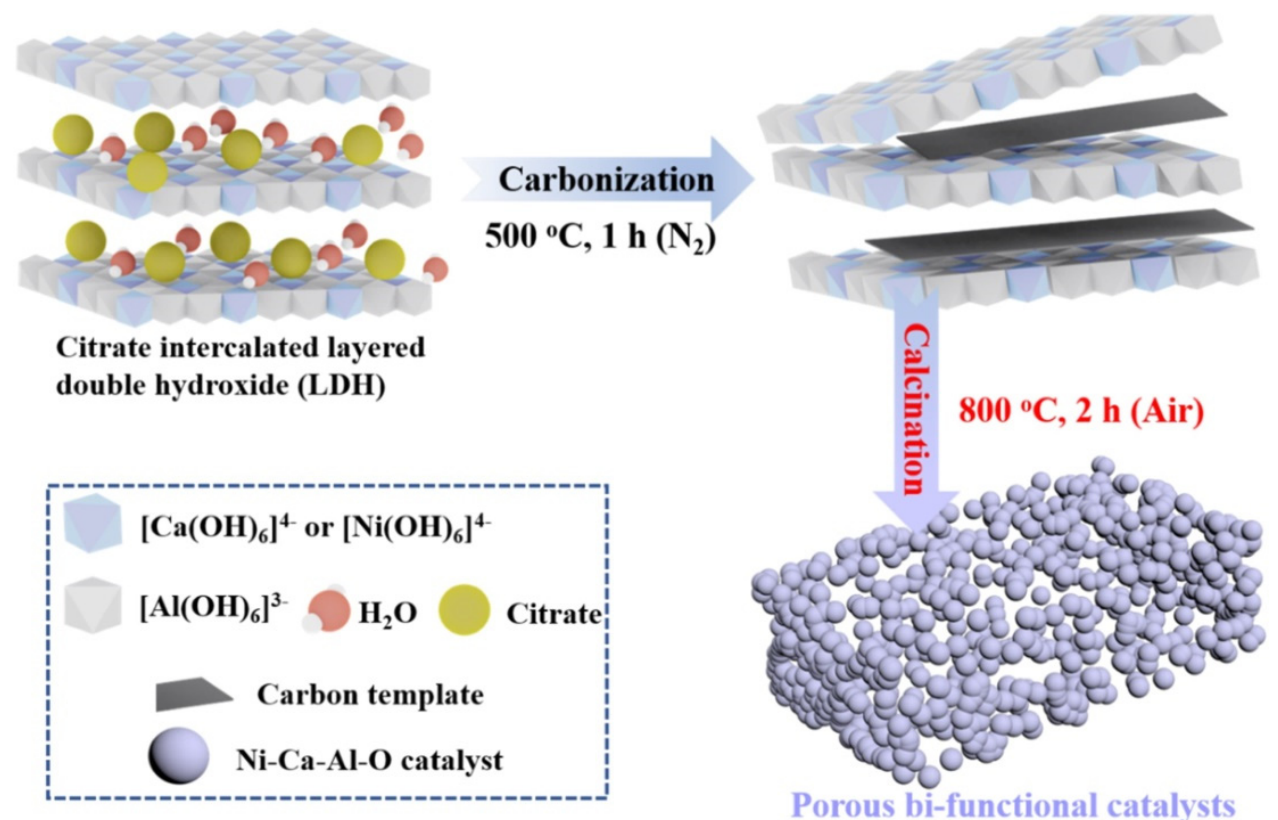

Figure 4. A new catalyst synthesis method for preparing a bifunctional catalyst used in the SESR reaction [74]. Copyright 2021, Elsevier.

\subsubsection{Chemical Looping Steam Reforming}

Chemical looping steam reforming (CLSR) has been applied to produce $\mathrm{H}_{2}$ in a cyclic two-step process consisting of reduction and oxidation in the presence of a solid oxygen carrier (SOC), as depicted in Figure 5. CLSR allows the steam reforming process to be operated at a relatively lower temperature compared to conventional steam reforming by integrating an exothermic oxidation reaction with an endothermic reforming reaction [79]. Several studies have performed CLSR of glycerol for $\mathrm{H}_{2}$ production in moving-bed reactors $[80,81]$ or fixed-bed reactors $[82,83]$. As illustrated in Figure 5, fuel is loaded into a reforming reactor, where it is oxidized by a SOC either completely to form $\mathrm{CO}_{2}$ and $\mathrm{H}_{2} \mathrm{O}$ or partially to form $\mathrm{CO}$ and $\mathrm{H}_{2}$. The glycerol conversion and product selectivity are primarily dependent on the activity and stability of the SOC, and a superior SOC should offer dual functions including (i) being readily re-oxidized by air and reduced by fuel, and (ii) providing excellent catalytic performance in steam reforming and water gas shift reactions. The most commonly used SOCs are prepared by oxygen carriers such as $\mathrm{Fe}, \mathrm{Mn}$, $\mathrm{Co}$, and $\mathrm{Cu}[84]$ supported on porous catalyst supports such as $\mathrm{Al}_{2} \mathrm{O}_{3}, \mathrm{TiO}_{2}, \mathrm{ZrO}_{2}, \mathrm{SiO}_{2}$, and perovskites [85].

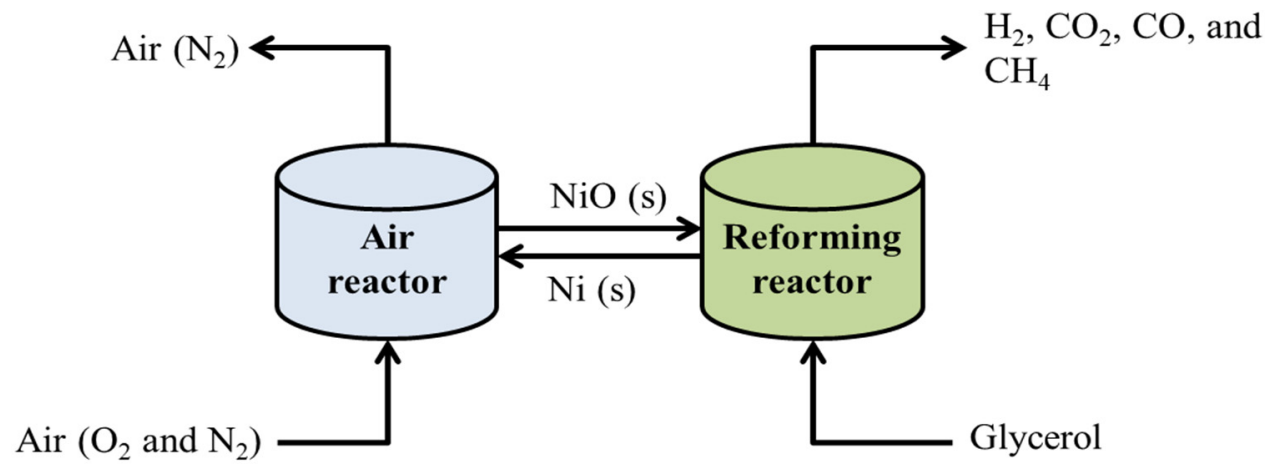

Figure 5. A schematic diagram for chemical looping steam reforming using $\mathrm{NiO}$ as the oxygen carrier [46]. 


\subsubsection{Sorption-Enhanced Chemical Looping Steam Reforming}

Previously, Rydén and Ramos [85] suggested combining CLSR and SESR in a one-step process (denoted as SECLR) to convert hydrocarbon to produce $\mathrm{H}_{2}$ using a fluidized bed reactor and a mixture of $\mathrm{NiO}$ and $\mathrm{CaO}$ as the bed material, as shown in Figure 6. For the reforming reactor operated at a low temperature, hydrocarbon fuels are partially oxidized by the $\mathrm{NiO}$ and steam, as shown in Equations (13) and (14), respectively.

$$
\begin{gathered}
\mathrm{CH}_{4}+\mathrm{NiO} \rightarrow \mathrm{CO}_{2}+2 \mathrm{H}_{2} \mathrm{O}+4 \mathrm{Ni} \\
\mathrm{CH}_{4}+\mathrm{NiO} \rightarrow \mathrm{CO}+2 \mathrm{H}_{2}+\mathrm{Ni}
\end{gathered}
$$

The resulting $\mathrm{CO}_{2}$ is then captured by $\mathrm{CaO}$, resulting in the promotion of the water gas shift reaction, as illustrated in Equation (15). The overall reaction involved in the reforming reactor is approximately thermo-neutral.

$$
\mathrm{CaO}+\mathrm{CO}_{2} \leftrightarrow \mathrm{CaCO}_{3}
$$

The calcination reactor is operated at intermediate temperatures and the entire process is endothermic, in which $\mathrm{CO}_{2}$ is produced by $\mathrm{CaCO}_{3}$ decomposition to regenerate $\mathrm{CaO}$ (Equation (16)).

$$
\mathrm{CaCO}_{3} \leftrightarrow \mathrm{CaO}+\mathrm{CO}_{2}
$$

Additionally, a small flow of sweep gas consisting of $\mathrm{H}_{2} \mathrm{O}$ and $\mathrm{CO}_{2}$ might be needed to enhance fluidization. In the air reactor, SOC is re-oxidized by loading air into the reactor by Equation (17), and the overall reaction involved is exothermic.

$$
\mathrm{Ni}+1 / 2 \mathrm{O}_{2} \rightarrow \mathrm{NiO}
$$

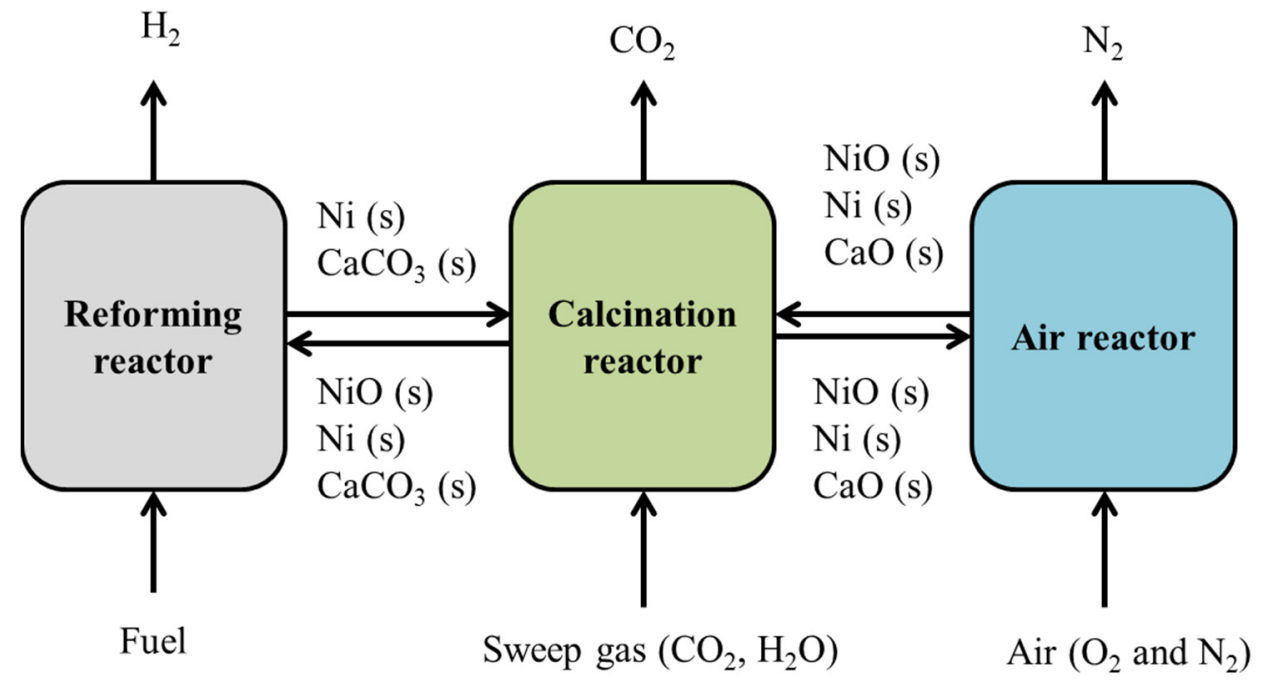

Figure 6. A schematic diagram for sorption-enhanced chemical looping reforming [53].

Compared to SESR, the SECLR process can be self-sufficient with heat since the $\mathrm{O}_{2}$ required in the oxidation is provided by the SOC rather than steam and the following re-oxidation of SOC can produce heat. With the help of solid circulation among the reactors, the SECLR process has the potential to be operated without an external heat source for heating or cooling [79]. However, to the best of our knowledge, no study has yet performed the SECLR of glycerol to produce $\mathrm{H}_{2}$, which could be an interesting direction for future research in order to develop an energy-sufficient $\mathrm{H}_{2}$ production route from glycerol.

To date, a wide range of noble-metals- and transition-metals-based catalysts supported on various supports with or without a promoter have been extensively tested to produce $\mathrm{H}_{2}$ 
from glycerol by steam reforming; however, catalyst deactivation caused by coke deposition and sintering over time is unavoidable, which consequently leads to decreases in catalytic performance and product selectivity. The detailed catalyst deactivation mechanism during the glycerol steam reforming was reviewed by Roslan et al. [23]. In particular, the cost for replacing fresh catalyst and shutdown of the industrial processes could be billions of dollars in general [23]. Despite the fact that poisoning is another cause for loss of catalytic activity, the compounds that could lead to poisoning in steam reforming are typically absent; thus, more efforts must be focused on the coke deposition and sintering of metal particles [32]. Lehnert and Claus [19] reported that the presence of $\mathrm{NaCl}$ in the crude glycerol led to the poisoning of metal species, thereby causing low crude glycerol conversion and fast catalyst deactivation. In addition to the new catalysts, a large amount of effort has been applied to the development of novel reactor configurations to further enhance production efficiency, including SESR, CLSR, and SECLR. For instance, SESR is capable for achieving in situ $\mathrm{CO}_{2}$ removal and thus shifts the water gas shift reaction (Equation (3)) toward producing more $\mathrm{H}_{2}$ gas and simultaneously limits methanation (Equation (5)) and coke formation (Equation (12)). In short, these newly developed technologies provide benefits to glycerol steam reforming by retarding the side reactions and, hence, promote $\mathrm{H}_{2}$ formation [32].

Until now, although steam reforming has been the dominant conversion route to produce $\mathrm{H}_{2}$, several emerging $\mathrm{H}_{2}$ production technologies have been developed for glycerol such as photo-reforming and catalytic transfer hydrogenation, which still require more studies to illustrate their underlying mechanisms, to develop more efficient catalysts, and to further optimize the operating parameters for increased conversion efficiency and selectivity [23].

\section{Utilization of Glycerol as Feedstock to Produce High-Value Chemicals}

In this section, the catalytic transformation of glycerol as the feedstock to produce acrolein by dehydration, lactic acid by oxidation, and 1,3-propanediol and 1,2-propanediol via selective hydrogenolysis is discussed, with a focus on the effect of the type of active metal species and catalyst support on the product yield and selectivity, and catalyst deactivation. The reaction conditions play important roles in regulating the reaction and affecting catalytic performance. The influence of operating conditions on the glycerol conversion to acrolein, lactic acid, and propanediols was thoroughly reviewed by Belousov [86], Abdullah et al. [87].

\subsection{Dehydration of Glycerol to Acrolein}

Acrolein (also called propenal), the simplest unsaturated aldehyde, is primarily used either as a biocide in drilling water or irrigation canals to control weed and algae or as a precursor to synthesize other chemicals such as acrylic acid, glutaraldehyde, and methionine [86]. In industry, acrolein is prepared by the gas phase partial oxidation of propene over a Bi/Mo-mixed oxide catalyst. Alternatively, glycerol can be used as the feedstock to prepare acrolein via catalytic dehydration in either the gas or liquid phase. The catalysts used in the catalytic dehydration of glycerol for the production of acrolein include supported zeolites [88], heteropoly acids (HPAs) [89], mixed metal oxides [90], phosphates [91], and pyrophosphates [91]. The reaction pathways for industrial acrolein preparation and glycerol to acrolein are depicted in Figure 7. For comparison, the dehydration of glycerol in gas phase offers advantages over dehydration of glycerol in the liquid phase in terms of the ease of products' separation and a higher acrolein yield [92]. The recent studies on catalytic dehydration of glycerol for producing acrolein are summarized in Table 4. 

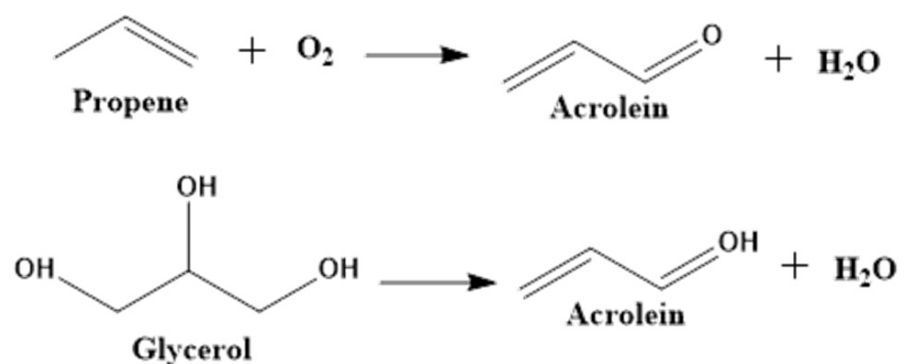

Figure 7. Two reaction pathways for acrolein preparation.

Table 4. A summary of recent studies on catalytic dehydration of glycerol to produce acrolein.

\begin{tabular}{|c|c|c|c|c|}
\hline Catalyst & $\operatorname{Temp}\left({ }^{\circ} \mathrm{C}\right)$ & $\begin{array}{c}\text { Glycerol } \\
\text { Conversion (\%) }\end{array}$ & $\begin{array}{l}\text { Selectivity } \\
\text { (\%) }\end{array}$ & Reference \\
\hline $\mathrm{MoP}$ & 240 & $41-50$ & $87-88$ & [9] \\
\hline $\mathrm{H}_{4} \mathrm{PMo}_{11} \mathrm{VO}_{40} / \mathrm{MCM}-41$ & 225 & 100 & $41-68$ & [93] \\
\hline $\mathrm{H}_{3} \mathrm{PW}_{12} \mathrm{O}_{40} / \mathrm{MSU}_{-\mathrm{x}}$ & 300 & 94-100 & $50-70$ & [94] \\
\hline $\begin{array}{c}\mathrm{WO}_{\mathrm{x}} / \mathrm{AlP} ; \mathrm{WO}_{\mathrm{x}} / \mathrm{ZrP} \\
\mathrm{WO}_{\mathrm{x}} / \mathrm{TiP}\end{array}$ & $300-340$ & $81-100$ & $51-80$ & [95] \\
\hline $\mathrm{WO}_{3} / \mathrm{ZrO}_{2} @ \mathrm{SiC}$ & $210-290$ & $45-100$ & $29-71$ & [96] \\
\hline $\mathrm{HY}$ & $250-325$ & $49-68$ & $38-74$ & [97] \\
\hline MOF-808 & 170 & 100 & 90 & [98] \\
\hline SAPO-34 & 285-375 & $38-56$ & $49-74$ & [99] \\
\hline $\begin{array}{l}\text { HZSM- } 5 \text { with modified } \\
\text { channel lengths in the } \\
\text { b axis }\end{array}$ & 320 & $85-99$ & $80-88$ & [100] \\
\hline $\begin{array}{l}\mathrm{PW} / \gamma-\mathrm{Al}_{2} \mathrm{O}_{3} \\
\mathrm{PMo} / \gamma-\mathrm{Al}_{2} \mathrm{O}_{3} \\
\mathrm{SiMo} / \gamma-\mathrm{Al}_{2} \mathrm{O}_{3}\end{array}$ & 280-350 & 33-94 & $11-46$ & [101] \\
\hline AlP; FeP; NiP & 280 & $89-98$ & $64-82$ & [102] \\
\hline $\begin{array}{c}\mathrm{STA} / \mathrm{SiO}_{2} ; \mathrm{HY} ; \mathrm{SO}_{4} / \mathrm{TiO}_{2} ; \\
\mathrm{ZnCl}_{2} / \mathrm{SiO}_{2} \\
\mathrm{HZSM}-5 ; \text { meso-HZSM-5; }\end{array}$ & 210 & 33-94 & $76-90$ & [103] \\
\hline $\begin{array}{c}\mathrm{CuHPO}_{4} / \text { meso-HZSM-5; } \\
\mathrm{Mo}_{1 / 3} \mathrm{HPO}_{4} / \text { meso- } \\
\text { HZSM-5; } \\
\mathrm{ZnHPO}_{\text {Zneso-HZSM-5; }} \text {; } \\
\mathrm{NiHPO}_{4} / \text { meso-HZSM-5; } \\
\mathrm{MnHPO}_{4} / \text { meso-HZSM-5 }\end{array}$ & 300 & I & $\begin{array}{l}\text { Yield: } \\
\text { 53-85 mol \% }\end{array}$ & [104] \\
\hline $\begin{array}{c}\mathrm{H}_{3} \mathrm{PW}_{12} \mathrm{O}_{40} ; \mathrm{Y}-\mathrm{ASA} ; \\
\mathrm{H}_{3} \mathrm{PW} / \mathrm{Y}-\mathrm{ASA} ;\end{array}$ & & & & \\
\hline $\begin{array}{c}\mathrm{Ni}_{0 \cdot 5} \mathrm{H}_{2} \mathrm{PW} / \mathrm{Y}-\mathrm{ASA} \\
\mathrm{Ni}_{1.0} \mathrm{HPW} / \mathrm{Y} \text {-ASA; } \\
\mathrm{Ni}_{1 \cdot 5} \mathrm{PW} / \mathrm{Y}-\mathrm{ASA} \\
\mathrm{Fe}_{0} \cdot{ }_{6} \text {-MFI-45-HS; }\end{array}$ & 320 & $33-82$ & $48-75$ & [105] \\
\hline $\begin{array}{c}\mathrm{Fe}_{0.6} \text {-MFI-60-PS; } \\
\mathrm{Fe} 0.6 \text {-MFI-60-IE; } \\
\mathrm{Fe}_{0 \cdot 6} \text {-MFI-60-Imp; } \\
\mathrm{Nc}_{\mathrm{C}}-\mathrm{Fe}_{0} \text {-MFI-45-PS }\end{array}$ & 320 & 94-99 & $71-96$ & [106] \\
\hline Nanosheet MFI & 320 & $<80-100$ & $82-87$ & [107] \\
\hline
\end{tabular}

Typically, the reactions of solid acid catalysts involved in the dehydration of glycerol include (i) the formation of acetol on the Lewis acid sites, and (ii) the formation of acrolein on Brønsted acid sites (Figure 8) [9]. Figure 3 shows that glycerol dehydration over a solid acid catalyst often results in the formation of 3-hydroxypropanal, which is accompanied by acetol formation as the by-product. The obtained 3-hydroxypropanal further proceeds with the dehydration reaction to form acrolein. Particularly, as suggested by Chai et al. [108], Brønsted acid sites are favorable for producing acrolein, and the formation of acetol is promoted by Lewis acid sites. In the presence of strong Brønsted acid sites, coke deposition 
might occur on the catalyst surface, thus leading to catalyst deactivation [109]. To reuse the spent catalyst, catalyst regeneration by burning off the coke can be carried out either continuously in situ or periodically ex situ [110]. Thus, the amount and strength of the acidic sites are essential to the catalytic dehydration of glycerol to produce acrolein with respect to unwanted side reactions and coke formation. For example, Viswanadham et al. [96] applied Keggin-type vanadium-containing phosphomolybdic acid $\left(\mathrm{H}_{4} \mathrm{PMo}_{11} \mathrm{VO}_{40}\right)$ supported on a mesoporous molecular sieve (i.e., $\mathrm{MCM}-41$ ) in glycerol dehydration, and the results showed that acrolein selectivity was proportional to the loading of $\mathrm{H}_{4} \mathrm{PMo}_{11} \mathrm{VO}_{40}$ up to $40 \mathrm{wt} \%$ and then decreased with further increases in $\mathrm{H}_{4} \mathrm{PMo}_{11} \mathrm{VO}_{40}$ loading. Based on the results from temperature-programmed desorption of ammonia (TPD- $\mathrm{NH}_{3}$ ), it was found that the concentration of $\mathrm{H}_{4} \mathrm{PMo}_{11} \mathrm{VO}_{40}$ is related to the acidity of the catalyst. Similar results were reported by Ginjupalli et al. [95], where the influence of the acidic strength of a range of tungsten oxide supported on metal phosphate catalysts on the catalytic performance, reaction variables, and reactant functionalities during the gas phase glycerol dehydration for acrolein production was evaluated. In addition to the type, amount, and strength of the acidic sites, the pore size of the catalyst is another important operational variable affecting the catalytic dehydration of glycerol. The porosity and distance of internal channels of the catalyst play a significant role in the diffusion and the adsorption-desorption of the molecules, thereby affecting coke formation on the catalyst surface. Ali et al. [100] evaluated the influence of $b$-axis channel length (i.e., 60-250 $\mathrm{nm}$ ) of HZSM-5 zeolites on the acrolein selectivity and coke formation obtained from glycerol dehydration, and the results showed that the HZSM- 5 catalyst with a $b$-axis channel length of $60 \mathrm{~nm}$ led to the highest glycerol conversion (100\%) and acrolein selectivity $(88 \%)$. The shortest channel length could lead to a high availability of active sites and improved diffusion, which, in turn, drastically limit coke formation. In terms of the effect of pore size, Zhang et al. [111] observed that hierarchical-structured zeolites with diverse meso-porosity demonstrated better stability and acrolein selectivity compared with conventional zeolites with sole microporous structure. Additionally, the presence of mesopores in the zeolites is helpful for making the catalyst more tolerant to coke formation, particularly in the case of an open and interconnected mesopore architecture. As suggested by the Kelvin equation (Equation (4)), catalyst deactivation might be caused by pore condensation, and a greater degree of pore condensation can be observed in the smaller mesoporous structures [112].

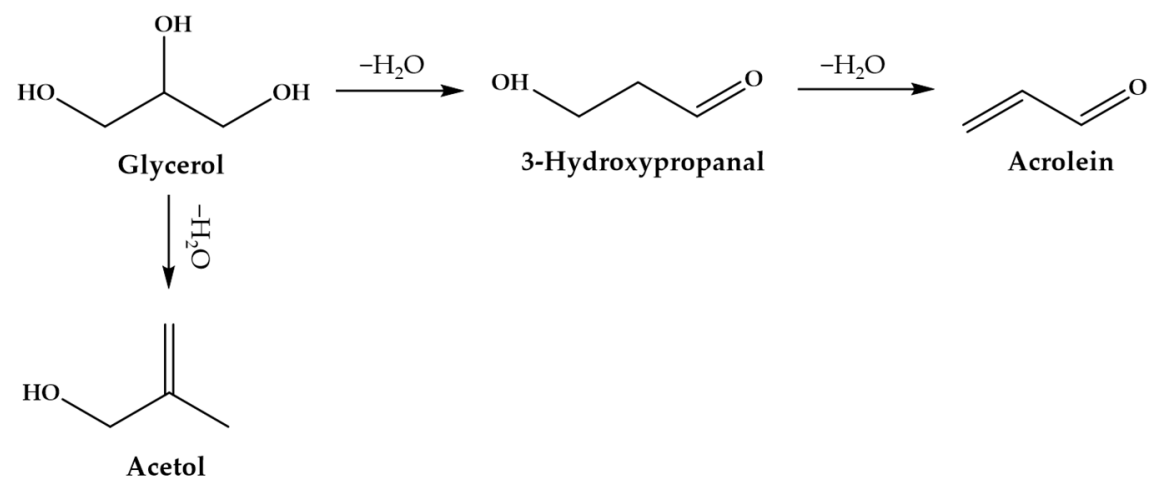

Figure 8. The reaction pathways for glycerol dehydration over a solid acid catalyst [63].

$$
R T \ln \left(\frac{P_{c}}{P_{0}}\right)=\frac{-2 \sigma_{V L} \cos \theta}{\left(n_{L}-n_{V}\right) H}
$$

where $P_{\mathrm{c}}$ and $P_{0}$ are the pressure at which pore condensation occurs and the saturated vapor pressure, respectively; $T$ and $R$ represent the absolute temperature and gas constant, respectively; $\sigma_{V L}$ is the vapor-liquid surface tension; $\theta$ represents the contact angle; $n_{L}$ and $n_{V}$ are the molar density of the bulk liquid and vapor phase, respectively; and $H$ is the pore width. 
Undeniably, coke formation and the associated catalyst deactivation are the major challenges faced by the catalytic dehydration of glycerol for acrolein production. The possible reaction pathways for coke formation during glycerol conversion to acrolein are shown in Figure 9. In addition to the modification of the pore size of the catalyst, as earlier discussed in this section, doping the catalyst with noble metals (e.g., $\mathrm{Ru}, \mathrm{Pt}$, or Pd) is another solution [113]. Doping $\mathrm{Ru}, \mathrm{Pd}$, or Pt into the catalyst together with $\mathrm{H}_{2}$ addition are effective in preventing coke formation through the hydrogenation of the coke precursors, consequently extending the catalyst's lifetime [113]. Trakarnpruk [114] reported that $\mathrm{Pt}$ doping in $\mathrm{H}_{3} \mathrm{PW}_{12} \mathrm{O}_{40} / \mathrm{Zr}-\mathrm{MCM}-41$ catalyst was capable of suppressing coke formation and dramatically enhancing catalyst stability. In another study, Ma et al. [115] synthesized and tested $\mathrm{H}_{3} \mathrm{PW}_{12} \mathrm{O}_{40} / \mathrm{MCM}-41, \mathrm{H}_{3} \mathrm{PW}_{12} \mathrm{O}_{40} / \mathrm{Zr}-\mathrm{MCM}-41$, and $\mathrm{Pd}_{-} \mathrm{H}_{3} \mathrm{PW}_{12} \mathrm{O}_{40} / \mathrm{Zr}-\mathrm{MCM}-41$ in the catalytic dehydration of glycerol for acrolein production, and the results indicated that $\mathrm{Pd}$ doping did not alter the mesoporous structure of the catalyst but decreased the specific surface area, pore volume, and pore size. Although no significant change was observed in the total acidity of the catalyst, the amount of Brønsted acid sites increased with a decrease in the amount of Lewis acid sites. Additionally, the use of $\mathrm{Pd}-\mathrm{H}_{3} \mathrm{PW}_{12} \mathrm{O}_{40} / \mathrm{Zr}-\mathrm{MCM}-41$ led to the highest glycerol conversion of $94 \%$ and acrolein selectivity of $85 \%$, which were accompanied by higher catalyst stability over $50 \mathrm{~h}$ of reaction compared to $\mathrm{H}_{3} \mathrm{PW}_{12} \mathrm{O}_{40} / \mathrm{Zr}$ MCM-41. The third approach to mitigate coke formation is co-feeding oxygen or air through the oxidation of coke precursors to form $\mathrm{CO}$ and $\mathrm{CO}_{2}$. Nadji et al. [90], for example, studied the effect of $\mathrm{O}_{2}$ on acrolein production from glycerol. When co-feeding $\mathrm{O}_{2}$, the glycerol conversion and acrolein selectivity were $100 \%$ and $85 \%$, respectively, during $8 \mathrm{~h}$ of reaction. Conversely, a significant decrease in the glycerol conversion from $99 \%$ to $55 \%$ was found after $8 \mathrm{~h}$ of reaction, along with a relatively lower acrolein selectivity ranging from $70 \%$ to $85 \%$. Based on the results, the authors speculated that co-feeding $\mathrm{O}_{2}$ in the glycerol dehydration is not only helpful for preventing the formation of coke but also suppressing acetol formation. Similar results were observed by Dalil et al. [116], where the dehydration of glycerol was performed over $\mathrm{WO}_{3} / \mathrm{TiO}_{2}$ in $10 \mathrm{~mol} \% \mathrm{O}_{2} / \mathrm{Ar}$ at $280{ }^{\circ} \mathrm{C}$. However, the presence of $\mathrm{O}_{2}$ promotes the formation of carboxylic acids (e.g., formic acid, acetic acid, and acrylic acid), which could be attributed to the oxidation of aldehydes [5]. Recently, Xie et al. [99] used microwave heating in the catalytic glycerol dehydration to prevent coke formation. Their newly designed microwave system consists of feedstock storage, peristaltic pump, preheater, quartz reactor, catalyst bed, microwave oven, infrared irradiation thermometer, temperature controller, liquid product storage, and water seal. The authors reported that the glycerol conversion (83.8\%) and acrolein selectivity (53.5\%) obtained from electric heating were lower than those obtained from microwave heating at $250{ }^{\circ} \mathrm{C}$ (glycerol conversion: $100 \%$ and acrolein selectivity: $71.1 \%$ ), which might be due to the differences in the heating mechanism between microwave heating and conventional heating. In conventional heating, heat is transferred from the reactor wall to the interior of the catalyst bed by conduction, resulting in a lower temperature at the interior of the catalyst bed. In microwave heating, the electromagnetic energy absorbed by the material is directly converted into heat at the molecular level. The major challenges for applying microwave irradiation in glycerol dehydration include safety issues, the lack of an accurate temperature measuring device, and the difficulty of selecting construction materials.

To date, many efforts have been aimed at suppressing coke formation and prolonging catalyst lifetime for glycerol dehydration to produce acrolein through (i) doping noble metals, (ii) modifying the porosity and channel length, and (iii) co-feeding $\mathrm{O}_{2}$; however, the catalysts will eventually be deactivated. Thus, catalyst regeneration by burning off the coke in air or $\mathrm{O}_{2}$ has been carried out through in situ regeneration [117] or periodic regeneration [118], but explosion might occur under high $\mathrm{O}_{2}$ concentration (i.e., 7\%) [113]. It is essential for future studies to design and develop innovative reactor configurations for the catalyst regeneration used in the catalytic dehydration of glycerol for producing acrolein. 


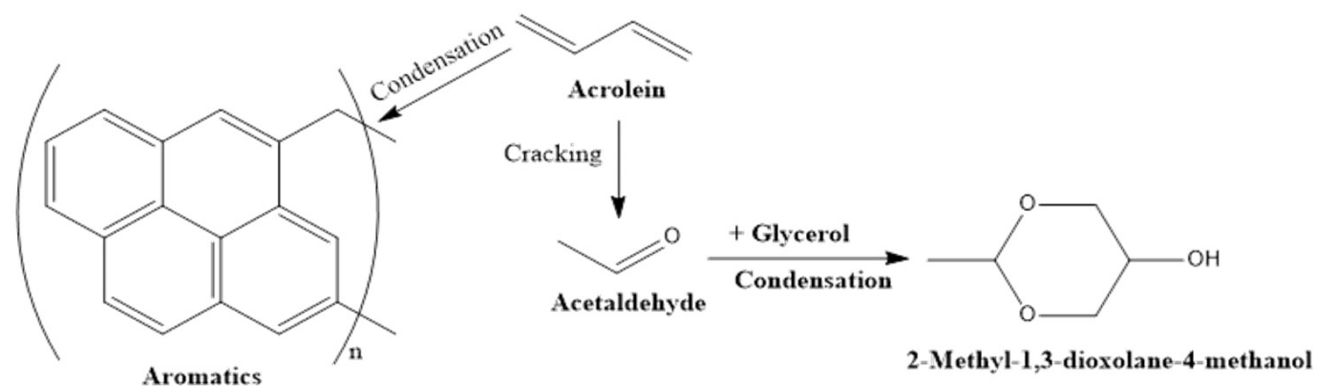

Figure 9. Possible reaction pathways for coke formation during catalytic dehydration of glycerol to produce acrolein [113]. Copyright 2021, Elsevier.

\subsection{Oxidation of Glycerol to Lactic Acid}

Lactic acid is an essential ingredient in the food industry as an acidulant or inhibitor for bacterial spoilage, in the textile industry as a mordant to improve color durability, in the cosmetic industry as a moisturizer, and in the dairy industry as a $\mathrm{pH}$ regulator, as well as an important monomer for manufacturing biopolymer polylactic acid (PLA) [119]. Traditionally, lactic acid is synthesized through sugar fermentation using carbohydrates as the carbon substrate; this method suffers from poor productivity and expensive operating costs due to the high cost of the enzyme, complex post-treatment by purification, and low scalability. As such, recent studies have employed glycerol as the feedstock to produce lactic acid via oxidation, as summarized in Table 5. The proposed reaction mechanism for converting glycerol to lactic acid via oxidation is depicted in Figure 10. As illustrated in Figure 10, glycerol conversion to lactic acid follows these steps:

i. Glycerol is initially dehydrogenated to glyceraldehyde in the presence of homogenous base and metal sites;

ii. Dehydration of glyceraldehyde is followed by keto-enol tautomerism to form pyrualdehyde;

iii. The formed pyrualdehyde is converted to lactic acid by an intra-molecular Cannizzaro reaction.

Table 5. A summary of recent studies on glycerol oxidation to produce lactic acid.

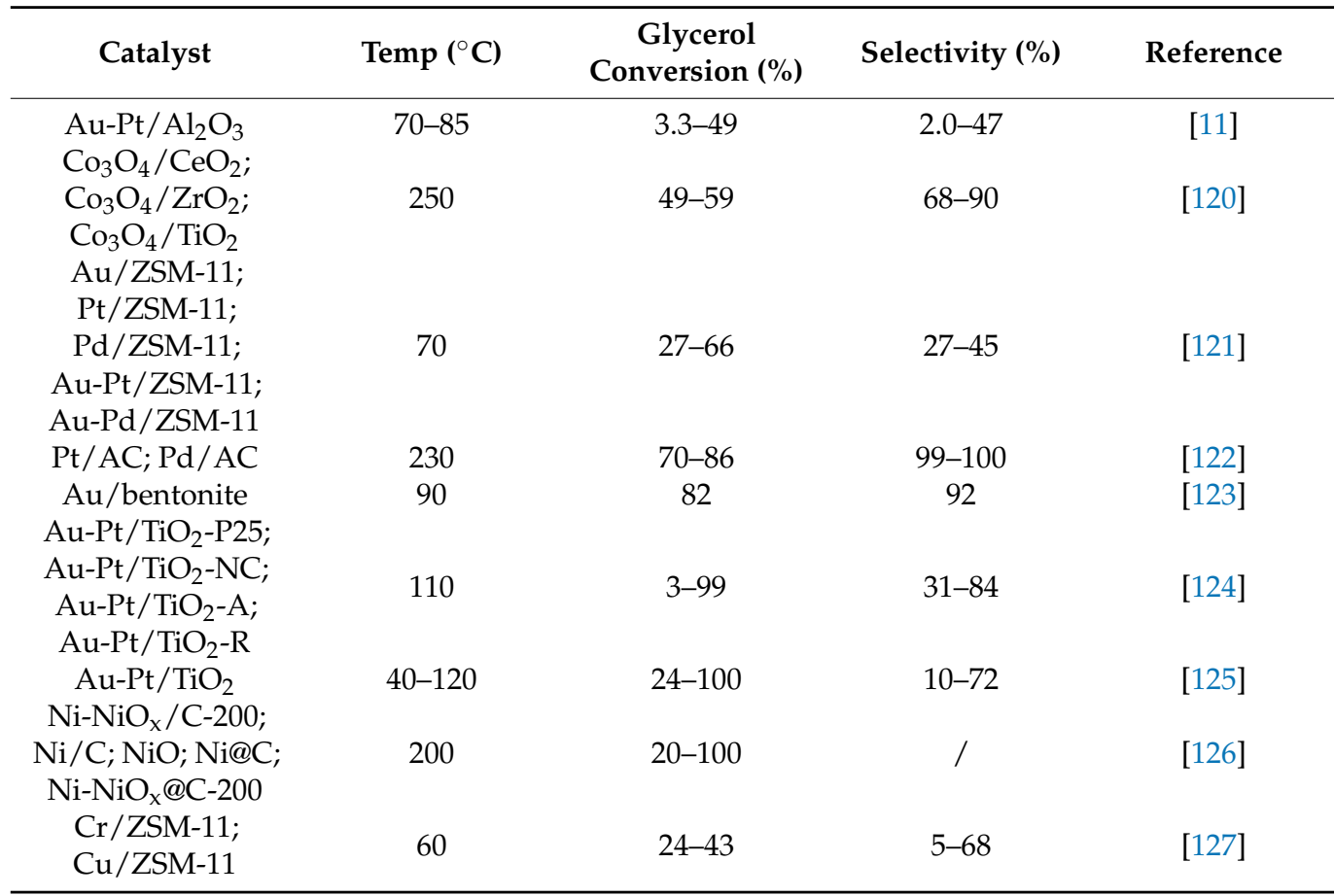


Table 5. Cont.

\begin{tabular}{ccccc}
\hline Catalyst & Temp $\left({ }^{\circ} \mathbf{C}\right)$ & $\begin{array}{c}\text { Glycerol } \\
\text { Conversion (\%) }\end{array}$ & Selectivity (\%) & Reference \\
\hline $\begin{array}{c}\mathrm{Zr}-\mathrm{Ce} / \mathrm{SBA}-15 \\
\mathrm{Pd} / \mathrm{HAP} ;\end{array}$ & $240-280$ & $59-81$ & $/$ & {$[128]$} \\
$\mathrm{Pd}_{0.75} / \mathrm{HAP} ;$ & 230 & $16-99$ & $2-90$ & {$[129]$} \\
$\mathrm{Pd}_{1.5}$ /HAP; HAP & & & & \\
\hline
\end{tabular}
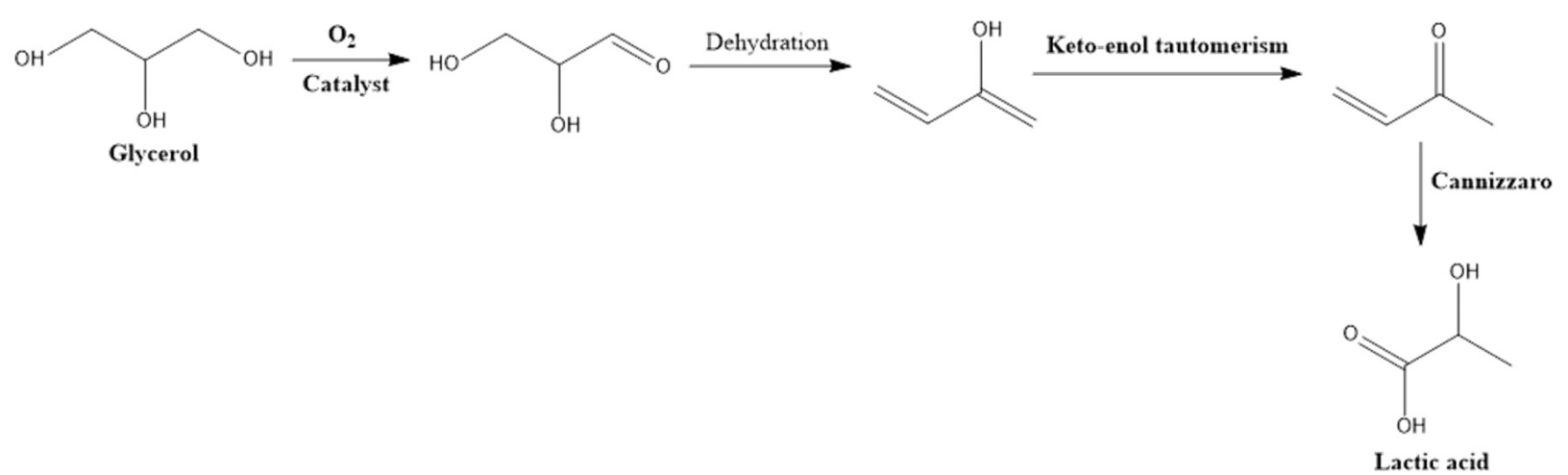

Figure 10. The reaction pathways for converting glycerol to lactic acid by oxidation [126]. Copyright 2021, Elsevier.

Alkali is capable of catalyzing dehydrogenation and dehydration reactions when subjected to hydrothermal conditions; thus, it has been extensively applied in lactic acid production from glycerol. For example, Zhang et al. [130] performed selective oxidation of glycerol over $\mathrm{Pt} / \mathrm{AC}$ to produce lactic acid in different basic solutions including $\mathrm{LiOH}$, $\mathrm{NaOH}, \mathrm{KOH}$, and $\mathrm{Ba}(\mathrm{OH})_{2}$, and the results showed that the order for lactic acid selectivity was as follows: $\mathrm{LiOH}>\mathrm{NaOH}>\mathrm{KOH}>\mathrm{Ba}(\mathrm{OH})_{2}$. The highest selectivity of lactic acid $(69.3 \%)$ was achieved at $90^{\circ} \mathrm{C}$ for $6 \mathrm{~h}$ and a LiOH-to-glycerol molar ratio of 1.5 , which achieved a glycerol conversion of $100 \%$. Despite the use of $\mathrm{Pt} / \mathrm{AC}$ demonstrating excellent catalytic stability in glycerol oxidation, it had a detrimental influence on the conversion of the intermediate toward lactic acid formation by shifting the reaction to form glyceric acid. Yang et al. [131] observed that 100\% glycerol conversion and $94.6 \%$ lactic acid selectivity were achieved when conducting oxidation in $\mathrm{NaOH}$ solution, at $180^{\circ} \mathrm{C}$, for $8 \mathrm{~h}$, and at 1.4 MPa of $\mathrm{N}_{2}$. Similarly, Yin et al. [132] tested different Cu-based catalysts (i.e., $\mathrm{Cu} /$ hydroxyapatite, $\mathrm{Cu} / \mathrm{MgO}$, and $\mathrm{Cu} / \mathrm{ZrO}_{2}$ ) for glycerol conversion to lactic acid in $\mathrm{NaOH}$ solution. They observed that both $\mathrm{Cu} /$ hydroxyapatite and $\mathrm{Cu} / \mathrm{MgO}$ exhibited better catalytic performance than $\mathrm{Cu} / \mathrm{ZrO}_{2}$, which was mainly due to the differences in the basicity among Cu-based catalysts. A maximum selectivity of lactic acid of $90 \%$ was obtained at $230{ }^{\circ} \mathrm{C}$ for $2 \mathrm{~h}$ and at a $\mathrm{NaOH}$ concentration of $1.1 \mathrm{~mol} / \mathrm{L}$, along with a $91 \%$ of glycerol conversion. Notably, glycerol conversion in alkaline solution is usually operated at severe conditions (i.e., temperature of $280-290^{\circ} \mathrm{C}$ ) as dehydrogenation is an energydemanding process. Nevertheless, alkali-assisted C-C bond cleavage might be simulated in harsh conditions, thereby leading to the formation of a series of undesirable by-products such as acetic acid, acrylic acid, formic acid, and oxalic acid. Consequently, to limit C-C bond cleavage forming undesired by-products, dehydrogenation must be performed at moderate conditions, which can be achieved using noble-metals-based catalysts (e.g., $\mathrm{Pt}$ and Pd). Feng et al. [133] synthesized a Pt-based catalyst (i.e., Pt/L-Nb ${ }_{2} \mathrm{O}_{5}$ ) and used it in the glycerol conversion for producing lactic acid under base-free conditions. The results showed that the presence of Lewis acid sites of $\mathrm{Pt} / \mathrm{L}-\mathrm{Nb}_{2} \mathrm{O}_{5}$ was helpful for the transformation of pyruvic aldehyde to lactic acid. The authors also reported that the selectivity of lactic acid and glycerol conversion were $91 \%$ and $81 \%$, respectively, when using $\mathrm{Pt} / \mathrm{L}-\mathrm{Nb}_{2} \mathrm{O}_{5}$ as the catalyst. Marques et al. [134] investigated glycerol conversion to lactic acid over Pd/C, and a 99\% glycerol conversion and a $46 \%$ lactic acid selectivity were 
obtained. In addition to $\mathrm{Pd}$ and $\mathrm{Pt}$, the efficiency of using Au-Pt or Au-Pd alloy in lactic acid production from glycerol oxidation was also assessed because: (i) Au is an effective catalyst for alcohol oxidation by molecular oxygen in the liquid phase; (ii) Au commonly shows excellent catalytic performance and is highly resistant to catalyst deactivation. Thus, several previous studies were carried out to apply $\mathrm{Au}-\mathrm{Pt} / \mathrm{C}$ [135], $\mathrm{Au}-\mathrm{Pt} / \mathrm{TiO}_{2}$ [136], or $\mathrm{Au}-\mathrm{Pt} / \mathrm{CeO}_{2}$ [137] in glycerol oxidation to enhance lactic acid production. In general, the use of bimetallic catalysts demonstrated improved catalytic performance in terms of glycerol conversion and lactic acid selectivity compared with monometallic catalysts [137]. However, noble-metals-based catalysts tend to be deactivated and show poor recyclability, which might result from over-oxidation, metal leaching and sintering, and poisoning by molecular oxygen. Catalyst deactivation could be limited, to some extent, by purging $\mathrm{N}_{2}$ into the catalyst support [138]. To enhance catalytic reducibility, several strategies have been developed [119]:

i. Pt and Pd supported by activated carbon showed great stability during glycerol oxidation to produce lactic acid;

ii. The development of bimetallic catalysts supported on $\mathrm{CeO}_{2}$ where insignificant loss in the catalytic activity was observed upon recycling five times;

iii. Adding non-noble metal promoters.

Overall, to date, a large gap remains in the development of excellent heterogeneous catalysts for the oxidation of glycerol for producing lactic acid; thus, more work is required.

\subsection{Selective Hydrogenolysis of Glycerol to 1,3-Propanediol}

1,3-propanediol has been extensively applied in the synthesis of polymers such polyethers, polyurethanes, and polyesters; most importantly, polypropylene terephthalate (PPT) fibers can be manufactured based on 1,3-propanediol and terephthalic acid [139]. During 1,3-propanediol formation, it is essential to selectively break down the secondary $\mathrm{C}-\mathrm{O}$ bond of glycerol, which still remains a big challenge because of the similarities in the activation energies among the three $\mathrm{C}-\mathrm{O}$ bonds of glycerol, thus complicating the discrimination. Additionally, the accessibility of the secondary $\mathrm{C}-\mathrm{O}$ bond is restricted due to steric hindrance [140]; it was reported that a range of by-products (e.g., 1-propanol and 2-propanol) can be generated in an excessive hydrogenolysis [141]. As shown in Figure 11, glycerol hydrogenolysis to produce 1,3-propanediol occurs on Brønsted acid sites at high a hydrogen pressure via Route 1 . At higher temperatures, more glycerol can be converted into 3-hydroxypropionaldehyde (3-HPA) as an intermediate, while the formation of acrolein and monoalcohols can be stimulated. Thus, the operating temperature applied in the hydrogenolysis of glycerol for 1,3-propadeniol is usually below $200{ }^{\circ} \mathrm{C}$. In addition to Brønsted acid sites, the hydrogenolysis reaction can also occur at Lewis acid sites where 1,2-propanediol formation is promoted by Route 2 . Glycerol is initially dehydrated to form hydroxyacetone, which further undergoes hydrogenation into 1,2-propanediol [142]. 


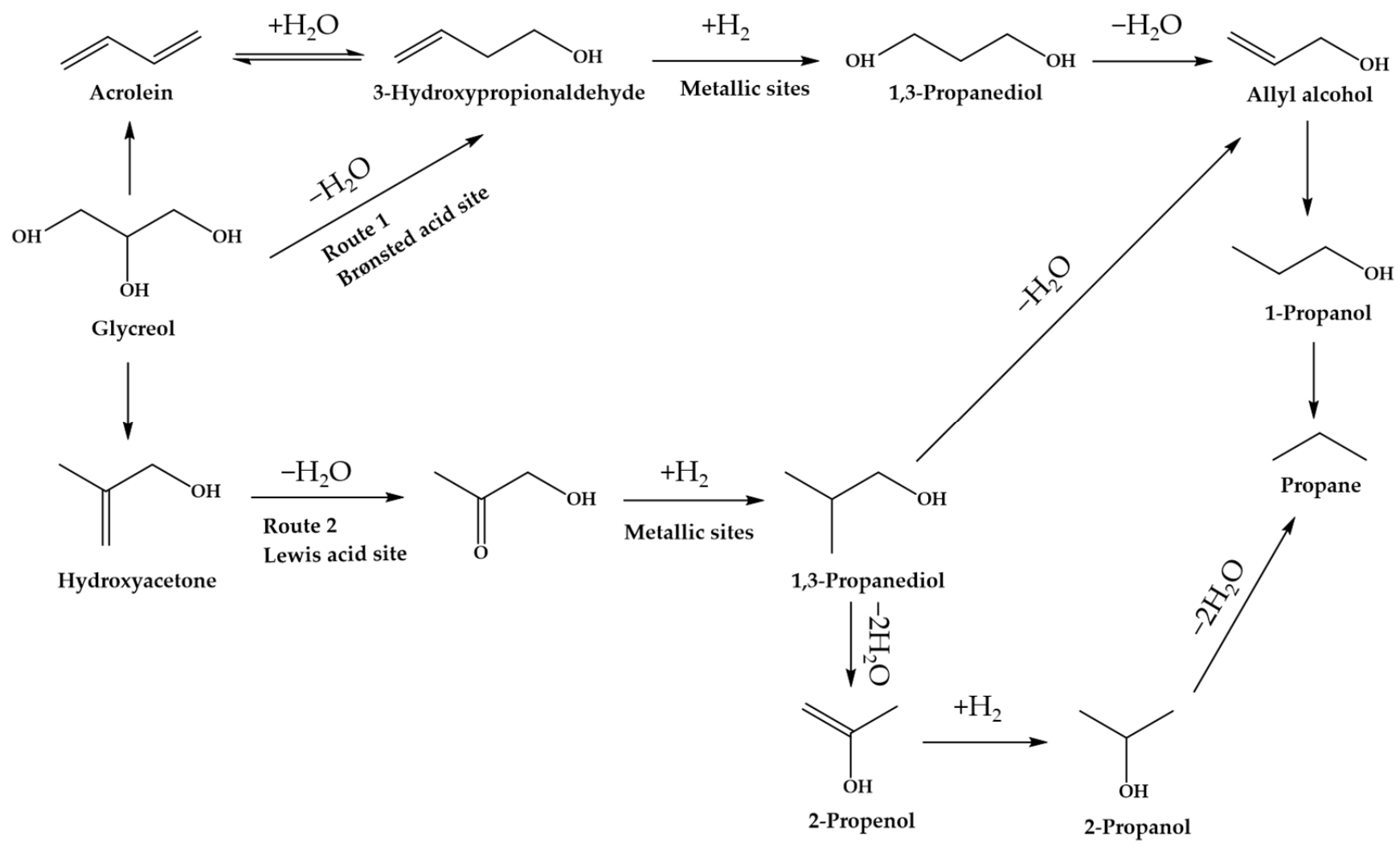

Figure 11. General reaction routes involved in the hydrogenolysis of glycerol [142].

Until now, a great deal of effort has been directed to the design of an effective catalyst that can improve the selectivity toward 1,3-propanediol formation, among which Pt-Wbased catalysts have recently been broadly investigated due to their suitable activity in the selective formation of 1,3-propanediol and potential industrial applications. Specifically, $\mathrm{Pt}-\mathrm{W}$-based catalysts offer dual roles including (i) active metal Pt species promoting the activation of $\mathrm{H}_{2}$ to provide the hydrogen source and (ii) Brønsted acid sites forming when the hydrogen species reach $\mathrm{WO}_{\mathrm{x}}$ species through hydrogen spillover, which is responsible for activating glycerol [141,142]. Edake et al. [143] investigated the hydrogenolysis of glycerol over $\mathrm{Pt}-\mathrm{WO}_{3} / \mathrm{Al}_{2} \mathrm{O}_{3}$ at $240-300{ }^{\circ} \mathrm{C}$ and ambient pressure in a fluidized bed reactor, and the highest glycerol conversion and 1,3-propanediol selectivity of $99 \%$ and $14 \%$, respectively, were attained at $260{ }^{\circ} \mathrm{C}$, a $\mathrm{H}_{2}$-to-glycerol ratio of 28 , and a WHSV of $0.14 \mathrm{~h}^{-1} . \mathrm{Al}_{2} \mathrm{O}_{3}$ is an efficient catalyst support that provides a higher surface area and serves as an anchor to fix glycerol on the surface, so has been regarded as one of the most effective supports used in glycerol hydrogenolysis to produce a high yield and selectivity of 1,3-propanediol, e.g., selectivity and yield of $66 \%$ and $42 \%$, respectively, as reported by $\mathrm{Zhu}$ et al. [144]. In addition to $\mathrm{Al}_{2} \mathrm{O}_{3}$, a variety of catalyst supports have been tested such as $\mathrm{SiO}_{2}$ [145], $\mathrm{ZrO}_{2}$ [146], $\mathrm{WO}_{3}$ [147], $\mathrm{AlPO}_{4}$ [148], SBA-15 [149], and $\mathrm{AlOOH}$ [150]. In a study, Priya et al. [95] evaluated the influence of the catalyst support on glycerol conversion into 1,3-propanediol at $260{ }^{\circ} \mathrm{C}, 10 \mathrm{wt} \%$ of glycerol loading, and a $0.1 \mathrm{MPa}$ of $\mathrm{H}_{2}$ initial pressure, and the tested supports included $\mathrm{ZrO}_{2}$, sulfated $\mathrm{ZrO}_{2}, \mathrm{Al}_{2} \mathrm{O}_{3}, \mathrm{AlPO}_{4}$, activated carbon, and Y-Zeolite. Among them, $\mathrm{AlPO}_{4}$ was identified as the best catalyst support, resulting in a glycerol conversion of $100 \%$ and a 1,3-propanediol selectivity of $35.4 \%$. The results suggested that the existence of weak acid sites play a positive role in the formation of 1,3-propanediol, and a high strength of weak acid sites was found in $\mathrm{Pt} / \mathrm{AlPO}_{4}$ based on the $\mathrm{NH}_{3}$-TPD analysis, ensuring the highest catalytic performance during the hydrogenolysis of glycerol for 1,3-propanediol production. In another study, Zhu et al. [151] modified $\mathrm{TiO}_{2}$-supported $\mathrm{Pt}^{-} \mathrm{WO}_{\mathrm{x}}$ catalyst by sulfate doping and then employed it in 1,3-propanediol production via hydrogenolysis since sulfate doping was 
reported to be helpful for increasing the surface area of the catalyst and improving metal dispersion [152]. The results showed that sulfate-doped $\mathrm{Pt}-\mathrm{WO}_{\mathbf{x}} / \mathrm{S}-\mathrm{TiO}_{2}$ achieved $100 \%$ glycerol conversion and $36 \%$ 1,3-propanediol selectivity at $120{ }^{\circ} \mathrm{C}$ and $4 \mathrm{MPa}$. Conversely hand, nonsulfate-doped $\mathrm{Pt}-\mathrm{WO}_{\mathrm{x}} / \mathrm{TiO}_{2}$ led to a significantly lower glycerol conversion of $57 \%$ but a higher selectivity of $66 \%$ toward 1,3-propanediol formation. This could be due to the over-strong hydrogenolysis activity of sulfate-doped catalyst. Subsequently, the addition of sulfate-doped $\mathrm{Pt}-\mathrm{WO}_{\mathrm{x}} / \mathrm{S}-\mathrm{TiO}_{2}$ was found to achieve a glycerol conversion of $75 \%$ and a 1,3-propanediol selectivity of $47 \%$ when lowering the severity of the reaction, i.e., temperature of $100{ }^{\circ} \mathrm{C}$, implying the beneficial impacts of sulfate on hydrogenolysis. This high hydrogenolysis efficiency offered by sulfate doping is related to the better dispersion of Pt and $\mathrm{WO}_{x}$ species and higher concentrations of Brønsted acid sites. Additionally, a better catalytic stability was detected when using the sulfate-doped $\mathrm{Pt}-\mathrm{WO}_{\mathrm{x}} / \mathrm{S}-\mathrm{TiO}_{2}$ as the catalyst, i.e., the glycerol conversion reduced from $100 \%$ to $83 \%$ and $82 \%$ at the third and fourth run, respectively, resulting from stronger antileaching in the presence of sulfate doping. Nevertheless, several challenges remain [141]:

i. A deep understanding of the synergistic influence between Pt species and $\mathrm{WO}_{\mathrm{x}}$ species is needed;

ii. Characterization tools to elucidate the correlation between glycerol activation and the surface and structure properties of catalyst are lacing;

iii. More effective catalysts must be developed for the selective hydrogenolysis of glycerol by different modification and catalyst preparation methods.

Apart from Pt-W-based catalysts, Ir-Re-based catalysts, as other widely investigated catalysts, have also been investigated to enhance 1,3-propanediol selectivity and yield from the hydrogenolysis of 1,3-propanediol [153-157]. Chanklang et al. [61], for instance, explored the effectiveness of using $\mathrm{Ir}-\mathrm{ReO}_{\mathrm{x}} / \mathrm{H}-\mathrm{ZSM}-5$ in glycerol hydrogenolysis to produce 1,3-propanediol at $180-240{ }^{\circ} \mathrm{C}$ and 2-8 $\mathrm{MPa}$ of $\mathrm{H}_{2}$ for $1-8 \mathrm{~h}$, and the incorporation of $\mathrm{Re}$ led to better Ir dispersion. They also found that a maximum yield of 1,3-propanediol of $2.8 \%$ with a glycerol conversion of $14.9 \%$ at $220^{\circ} \mathrm{C}$ and $4 \mathrm{MPa}$ of $\mathrm{H}_{2}$ for $8 \mathrm{~h}$. Liu et al. [154] synthesized an Ir-ReOx catalyst supported on $\mathrm{SiO}_{2}$, and the results showed that the highest 1,3-propanediol yield and selectivity were $32 \%$ and $47 \%$, respectively, at $120{ }^{\circ} \mathrm{C}$ and $8 \mathrm{MPa}$ of $\mathrm{H}_{2}$ for $24 \mathrm{~h}$, which was accompanied by a glycerol conversion of $69 \%$. In addition to H-ZSM- 5 and $\mathrm{SiO}_{2}$, KIT-6, as another ordered mesoporous silica with a cubic arrangement of interconnected pores, was also investigated in the preparation of an $\mathrm{Ir}-\mathrm{ReO}_{\mathrm{x}}$-based catalyst to enhance catalytic performance in glycerol hydrogenolysis for 1,3-propanediol production [157]. Re is a rare earth element, which significantly hinders its large-scale application. The most recent investigations into the hydrogenolysis of glycerol to produce 1,3-propanediol in the presence of either Pt-W-based catalysts or Ir-Re-based catalysts are summarized in Table 6 .

Table 6. A summary of recent studies on glycerol hydrogenolysis to 1,3-propanediol.

\begin{tabular}{ccccc}
\hline Catalyst & Temp $\left({ }^{\circ} \mathrm{C}\right)$ & $\begin{array}{c}\text { Glycerol } \\
\text { Conversion (\%) }\end{array}$ & Selectivity (\%) & References \\
\hline $\mathrm{Pt}-\mathrm{WO}_{\mathrm{x}} / 0.5 \mathrm{MCF} ;$ & & & & \\
$\mathrm{Pt}-\mathrm{WO}_{\mathrm{x}} / 1.0 \mathrm{MCF} ;$ & 150 & $37-100$ & $61-66$ & \\
$\mathrm{Pt}-\mathrm{WO}_{\mathrm{x}} / 1.5 \mathrm{MCF} ;$ & & & \\
$\mathrm{Pt}-\mathrm{WO}_{\mathrm{x}} / 2 \mathrm{MCF} ;$ & & & \\
$\mathrm{Pt}-\mathrm{WO}_{\mathrm{x}} / 2.5 \mathrm{MCF}$ & & & \\
$\mathrm{Pt}-\mathrm{WO}_{\mathrm{x}} / \mathrm{Al}_{2} \mathrm{O}_{3}$ & & & \\
$\quad($ rod-like); & & $19-80$ & \\
$\mathrm{Pt}-\mathrm{WO}_{\mathrm{x}} / \mathrm{Al}_{2} \mathrm{O}_{3}$ & 160 & & \\
$\quad($ flake-like); & & & \\
$\mathrm{Pt}-\mathrm{WO}_{\mathrm{x}} / \mathrm{Al}_{2} \mathrm{O}_{3}$ & & & \\
(spindle-like) & & & \\
\hline
\end{tabular}


Table 6. Cont.

\begin{tabular}{|c|c|c|c|c|}
\hline Catalyst & Temp $\left({ }^{\circ} \mathrm{C}\right)$ & $\begin{array}{c}\text { Glycerol } \\
\text { Conversion (\%) }\end{array}$ & Selectivity (\%) & References \\
\hline $\begin{array}{c}\mathrm{Ir}-\mathrm{ReOx} / \mathrm{H}-\mathrm{ZSM}-5 ; \\
\mathrm{Ir}-\mathrm{ReO}_{\mathrm{x}} / \mathrm{TiO}_{2} ; \\
\mathrm{Ir}-\mathrm{ReO}_{\mathrm{x}} / \mathrm{SiO}_{2}\end{array}$ & 200 & $2-6$ & $13-34$ & [153] \\
\hline $\begin{array}{c}\mathrm{Pt} / \mathrm{Al}_{2} \mathrm{O}_{3} \\
\mathrm{Pt}-\mathrm{WO}_{\mathrm{x}} / \mathrm{Al}_{2} \mathrm{O}_{3}\end{array}$ & 140 & $23-36$ & / & [158] \\
\hline $\mathrm{Pt} / \mathrm{SiO}_{2} ; \mathrm{Pt}-\mathrm{WO}_{\mathrm{x}} / \mathrm{SiO}_{2}$ & 180 & $16-64$ & $48-57$ & [159] \\
\hline $\mathrm{Pt}-\mathrm{WO}_{\mathrm{x}} / \mathrm{Al}_{2} \mathrm{O}_{3}$ & 180 & 58 & 40 & [160] \\
\hline $\begin{array}{c}\mathrm{Pt}-\mathrm{WO}_{\mathrm{x}} / \mathrm{SiO}_{2}-\mathrm{Al}_{2} \mathrm{O}_{3} \\
\mathrm{SiO}_{2}-\mathrm{Al}_{2} \mathrm{O}_{3} \\
\mathrm{Pt}-\mathrm{WO}_{\mathrm{x}} / \mathrm{SiO}_{2} \\
\mathrm{Pt}-\mathrm{WO}_{\mathrm{x}} / \mathrm{ZrO}_{2}\end{array}$ & 210 & $1-64$ & $0-27$ & [161] \\
\hline $\begin{array}{c}\mathrm{Pt}-\mathrm{WO}_{\mathrm{x}} / \mathrm{TiO}_{2} \\
\mathrm{Pt}-\mathrm{WO}_{\mathrm{x}} / \mathrm{ZrO}_{2}-\mathrm{TiO}_{2}\end{array}$ & 140 & $26-74$ & $32-40$ & [162] \\
\hline $\begin{array}{c}\text { Pt-WO } / \text { /SAPO-34; } \\
\text { SAPO-34; Pt/SAPO-34 }\end{array}$ & 210 & $0-48$ & $6-19$ & [163] \\
\hline
\end{tabular}

\subsection{Selective Hydrogenolysis of Glycerol to 1,2-Propanediol}

Currently, the transformation of glycerol into 1,2-propanediol by selective hydrogenolysis has received much attention due to the ability of 1,2-propanediol as an industrial monomer to produce polyester resins, detergents, antifreeze agents, additives in paint, food, etc. Industrially, 1,2-propanediol is synthesized through the hydration of propylene [164]. When using glycerol as the feed, selective hydrogenolysis of glycerol for producing 1,2-propanediol has been extensively carried out over noble metals (e.g., $\mathrm{Pd}, \mathrm{Pt}$, and $\mathrm{Ru}$ ) because of their capability to active hydrogen molecules. Oberhauser et al. [165] found that Pt nanoparticles supported on carbonaceous catalyst supports can catalyze glycerol hydrogenolysis at 160 and $180^{\circ} \mathrm{C}$. The used carbonaceous supports were Katjen Black EC-600JD, Vulcan XC-72, and fewer-layer graphene. Among them, Katjen Black EC-600JD exhibited the highest surface area and contributed to retarding the agglomeration of metal nanoparticles, along with showing the highest selectivity for 1,2-propanediol of $70 \%$, achieved at $160{ }^{\circ} \mathrm{C}$. Silveira et al. [166] prepared a Ru catalyst supported on sugarcane-straw-derived active carbon and commercial activated carbon, which was tested by conducting glycerol hydrogenolysis at $200{ }^{\circ} \mathrm{C}, 5 \mathrm{MPa}, 6 \mathrm{~h}$, and $10 \mathrm{vol} \%$ of glycerol loading. The results showed that the formation of 1,2-propanediol was more favorable than 1,3-propanediol formation under the investigated conditions, which might be due to the dominance of Lewis sites. To further enhance the performance of Ru-based catalysts in glycerol hydrogenolysis, Sherbi et al. [16] added another metal, $\mathrm{Cu}$, into the preparation of Ru-based catalyst supported on carbon nanotubes (CNTs), and this developed catalyst reached $93.4 \%$ 1,2-propanediol selectivity at $200{ }^{\circ} \mathrm{C}, 5 \mathrm{MPa}$ of $\mathrm{H}_{2}, 20 \mathrm{~h}$, and $20 \mathrm{wt} \%$ of glycerol loading, along with glycerol conversion of $18 \%$. Similar results were reported by Wu et al. [167], where Ru-Cu/CNT catalysts were applied in glycerol hydrogenolysis to enhance 1,2-propanediol production, and the results showed that the bimetallic catalysts showed a higher selectivity toward 1,2-propanediol formation than single-metal catalysts due to the hydrogen spillover effect resulting from the presence of highly dispersed tiny $\mathrm{Ru}$ clusters on the surface of $\mathrm{Cu}$ particles. The main benefits of using Ru-based catalysts for glycerol hydrogenolysis were reviewed [168], as indicated below:

i. The combination of active metal particles and acid support could lead to the formation of 1,2-propanediol as the main product throughout glycerol conversion, especially under mild conditions (i.e., temperature below $180^{\circ} \mathrm{C}$ );

ii. The occurrence of over-hydrogenolysis in the presence of Ru-based catalysts can be identified when conducting the reaction under severe conditions (i.e., temperature above $240{ }^{\circ} \mathrm{C}$ ), which causes the product formation to shift from 1,2-propanediol to 1-propanol and propane. 
$\mathrm{Pd}$, as another noble metal, has also been used to synthesize catalysts in the 1,2propanediol production from glycerol. Mauriello et al. [169] studied the hydrogenolysis of glycerol at $180^{\circ} \mathrm{C}$ and 5 bar without adding hydrogen gas; instead, an external hydrogen source, i.e., 2-propanol, was used as the reaction medium, and the investigated catalysts included $\mathrm{Pd} / \mathrm{Co}, \mathrm{Pd} / \mathrm{CoO}, \mathrm{Pd} / \mathrm{Co}_{3} \mathrm{O}_{4}, \mathrm{Pd} / \mathrm{Fe}, \mathrm{Pd} / \mathrm{Fe}_{2} \mathrm{O}_{3}, \mathrm{Pd} / \mathrm{Fe}_{2} \mathrm{O}_{3}$, and $\mathrm{Pd} / \mathrm{SiO}_{2}$. The interaction between $\mathrm{Pd}$ and other metals (i.e., $\mathrm{Co}$ and $\mathrm{Fe}$ ) can modify the electronic properties of $\mathrm{Pd}$ and results in the formation of bimetallic $\mathrm{Pd}-\mathrm{Co}$ or Pd-Fe sites, thereby promoting catalytic performance in the hydrogenolysis of glycerol, creating a shift toward 1,2-propanediol production. In addition to noble metals, transition metals such as $\mathrm{Ni}$ [170], $\mathrm{Cu}$ [171], and Co [172] have been broadly explored in the selective hydrogenolysis of glycerol to generate 1,2-propanediol due to their low price and high activity and selectivity [173]. Among them, Cu-based catalysts are the most commonly utilized catalysts in glycerol hydrogenolysis, which is primarily related to their strong ability to cleave $\mathrm{C}-\mathrm{O}$ bonds [164]. To date, $\mathrm{Cu}$-based catalysts, either monometallic or bimetallic, have been designed: $\mathrm{Cu}-\mathrm{Zn} / \mathrm{Al}_{2} \mathrm{O}_{3}$ by Mishra et al. [171], $\mathrm{Cu} / \mathrm{SiO}_{2}$ by Shan et al. [174], $\mathrm{Cu}$ $\mathrm{Ni} / \mathrm{Y}$ zeolite by de Andrade et al. [175], $\mathrm{Cu} / \mathrm{ZnO}$ by Wang et al. [176], $\mathrm{Cu} /$ metal oxides (i.e., $\mathrm{Al}_{2} \mathrm{O}_{3}, \mathrm{SiO}_{2}, \mathrm{ZnO}$, and $\mathrm{MgO}$ ) by $\mathrm{Zhou}$ et al. [177], $\mathrm{Cu} / \mathrm{AlOOH}$ by Wu et al. [178], $\mathrm{Cu}-\mathrm{Ni} / \mathrm{SiO}_{2}$ by Lee et al. [179], $\mathrm{Cu}-\mathrm{Ru} / \mathrm{TiO}_{2}$ by Salazar et al. [180], $\mathrm{Cu}-\mathrm{Ni} / \mathrm{Al}_{2} \mathrm{O}_{3}$ by Poddar et al. [181], and Co/dolomite by Azri et al. [182]. The underlying mechanism involved in Cu-catalyzed glycerol hydrogenolysis was reviewed by Montassier et al. [183]. Initially, glycerol is dehydrogenated on $\mathrm{Cu}$ to produce glyceraldehyde, and then the formation of 1,2-propanediol is achieved through a nucleophilic reaction of water or absorbed $\mathrm{OH}$ species, dihydroxylation, and hydrogenation of aldehyde (2-hydroxy acrolein) [164]. The relevant studies on the selective hydrogenolysis of glycerol for 1,2-propanediol production over either noble-metals-based catalysts or transition-metals-based catalysts are summarized in Table 7. Several studies have been performed to compare the catalytic performance amongst various noble-metals-based and transition-metals-based catalysts in 1,2-propanediol production by glycerol hydrogenolysis. For example, Kang et al. [184] prepared and characterized various bimetallic catalysts including Pt-Cu/SiO $2, \mathrm{Pd}-\mathrm{Cu} / \mathrm{SiO}_{2}$, $\mathrm{Ag}-\mathrm{Cu} / \mathrm{SiO}_{2}$, and $\mathrm{Ni}-\mathrm{Cu} / \mathrm{SiO}_{2}$ using a series of analytical techniques, and found that Pt$\mathrm{Cu} / \mathrm{SiO}_{2}$ demonstrated the largest metal particles dispersion and smallest particle size. In the following hydrogenolysis investigation at $200{ }^{\circ} \mathrm{C}, 4 \mathrm{MPa}$ of $\mathrm{H}_{2}$, and $12 \mathrm{~h}$, the authors reported that using $\mathrm{Pt}-\mathrm{Cu} / \mathrm{SiO}_{2}$ led to an almost $100 \%$ glycerol conversion and the highest selectivity to 1,2-propanediol of $96 \%$ of the considered bimetallic catalysts (i.e., $\mathrm{Pd}-\mathrm{Cu} / \mathrm{SiO}_{2}$, $\mathrm{Ag}-\mathrm{Cu} / \mathrm{SiO}_{2}$, and $\mathrm{Ni}-\mathrm{Cu} / \mathrm{SiO}_{2}$ ) and monometallic catalysts (i.e., $\mathrm{Cu} / \mathrm{SiO}{ }_{2}$ and $\mathrm{Pt} / \mathrm{SiO}_{2}$ ). This was accompanied by a relatively high catalytic stability offered by $\mathrm{Pt}-\mathrm{Cu} / \mathrm{SiO}_{2}$, which could be due to the decreased metal agglomeration tendency in the presence of Pt. Von Held Soares et al. [185] conducted glycerol hydrogenolysis over $\mathrm{Pt} / \mathrm{Fe}_{3} \mathrm{O}_{4}, \mathrm{Pd} / \mathrm{Fe}_{3} \mathrm{O}_{4}$, and $\mathrm{Ni} / \mathrm{Fe}_{3} \mathrm{O}_{4}$, and the order of catalytic activity was as follows: $\mathrm{Pt}>\mathrm{Pd}>\mathrm{Ni}$.

Overall, the transformation of glycerol to value-added $C_{3}$ chemicals (i.e., acrolein, lactic acid, 1,3-propanediol, and 1,2-propanediol) over heterogeneous catalysts is an essential component of achieving the sustainable and economic production of biodiesel. To ensure a high yield of the target products, proper catalyst design including the selection of active metal species, support material, catalyst preparation method, and the type and strength of acid sites) and reaction conditions must be carefully determined. 
Table 7. A summary of recent studies on glycerol hydrogenolysis to produce 1,2-propanediol.

\begin{tabular}{|c|c|c|c|c|}
\hline Catalyst & Temp $\left({ }^{\circ} \mathrm{C}\right)$ & $\begin{array}{c}\text { Glycerol } \\
\text { Conversion (\%) }\end{array}$ & Selectivity (\%) & Reference \\
\hline $\begin{array}{c}\mathrm{Pt} / \mathrm{Al}_{2} \mathrm{O}_{3} ; \\
\mathrm{In} / \mathrm{Al}_{2} \mathrm{O}_{3} ; \mathrm{Pt}-\mathrm{In} / \mathrm{A} \\
\mathrm{Al}_{2} \mathrm{O}_{3} ; \mathrm{Pt} / \mathrm{SiO}_{2}\end{array}$ & 240 & $1-39$ & $16-49$ & [115] \\
\hline $\begin{array}{c}\mathrm{In} / \mathrm{SiO}_{2} ; \mathrm{Pt}-\mathrm{In} / \mathrm{SiO}_{2} \\
\mathrm{Cu} / \mathrm{MgO} ; \\
\mathrm{Cu}-\mathrm{Ru} / \mathrm{MgO}\end{array}$ & 220 & $9-48$ & $7-17$ & [116] \\
\hline $\begin{array}{l}\mathrm{Cu} / \mathrm{Dol} ; \mathrm{Ni} / \mathrm{Dol} ; \\
\mathrm{Co} / \mathrm{Dol} ; \mathrm{Fe} / \mathrm{Dol} ; \\
\text { Zn/Dol; Dolomite }\end{array}$ & 200 & $9-79$ & $0-79$ & [170] \\
\hline $\begin{array}{c}\mathrm{Cu} / \mathrm{Ga}_{2} \cdot 3-\mathrm{HT} \\
\mathrm{Ni} / \mathrm{NaY} \text {-zeolite; }\end{array}$ & 300 & 21-95 & 0-97 & [173] \\
\hline $\begin{array}{c}\mathrm{Cu} / \mathrm{NaY} \text {-zeolite; } \\
\text { Ni-Cu/NaY-zeolite } \\
\mathrm{Ni}-\mathrm{Cu} / \mathrm{Al}_{2} \mathrm{O}_{3} \text {; }\end{array}$ & 260 & $71-96$ & $13-44$ & [175] \\
\hline $\begin{array}{c}\mathrm{Ni} / \mathrm{SiO}{ }_{2} ; \mathrm{Ni} / \mathrm{WO}_{3} \\
\mathrm{Ni} / \mathrm{B}-\mathrm{Al}_{2} \mathrm{O}_{3} \\
\mathrm{Ru}-\mathrm{Cu} / \mathrm{m}-\mathrm{ZrO}_{2}\end{array}$ & 200 & $1-67$ & $0-90$ & [181] \\
\hline $\begin{array}{l}\mathrm{Ru}-\mathrm{Cu} / \mathrm{CaO}-\mathrm{ZrO}_{2} \\
\mathrm{Ru}-\mathrm{Cu} / \mathrm{SO}_{4}-\mathrm{ZrO}_{2} \\
\mathrm{Ru}-\mathrm{Cu} / \mathrm{WO}_{3}-\mathrm{ZrO}_{2}\end{array}$ & 180-200 & $1-30$ & $51-87$ & [186] \\
\hline $\begin{array}{l}\mathrm{Ru} / \mathrm{K}-\mathrm{OMS}-2 ; \\
\mathrm{Cu} / \mathrm{K}-\mathrm{OMS}-2 ; \\
\mathrm{Ni} / \mathrm{K}-\mathrm{OMS}-2\end{array}$ & $180-220$ & $32-100$ & 69-91 & [187] \\
\hline
\end{tabular}

\section{General Catalyst Preparation Strategies and Associated Characterization Methods}

In addition to the type of active metal and catalyst support, catalyst preparation is another important factor affecting catalytic performance and product yield and selectivity in the catalytic transformation of glycerol to fuels and chemicals [188]. The most used catalyst preparation methods in catalytic glycerol valorization include: impregnation [35], hydrothermal [160], precipitation [189], sol-gel [190], and wet incipient [191] methods. Among them, the methods commonly used for catalyst preparation are impregnation and precipitation. Impregnation is mainly dependent on the interaction between the surface of the support and the species in the prepared solution, which can be further divided into wet impregnation and dry impregnation according to the volume of impregnation solution introduced to the pores of the support material. In comparison, the main benefit offered by dry impregnation is that the amount of added components to the catalyst is easier to control than wet impregnation; however, the catalyst synthesized by dry impregnation might not be as uniform as that prepared by wet impregnation [192]. Precipitation is the most widely applied catalyst preparation method because of its low cost and simplicity. For example, several industrially used catalysts are prepared by precipitation or co-precipitation such as $\mathrm{SiO}_{2}-\mathrm{Al}_{2} \mathrm{O}_{3}$ used in fluid catalytic cracking (FCC), $\mathrm{Fe}_{2} \mathrm{O}_{3}$ applied in the Fisher Tropsch process, and $\mathrm{Cu}-\mathrm{ZnO} / \mathrm{Al}_{2} \mathrm{O}_{3}$ employed in methanol synthesis [193]. To the best of our knowledge, no study has yet compared different catalysts preparation methods in terms of their activity, stability, and reducibility during glycerol transformation, which could be a future research direction. After catalyst synthesis, a series of analytical techniques is needed to determine the characteristics of the prepared catalysts, and the most widely applied characterization methods are $\mathrm{X}$-ray fluorescence spectrometry, $\mathrm{N}_{2}$ adsorptiondesorption analysis, $\mathrm{X}$-ray diffractometry (XRD), transmission electron microscopy (TEM), and temperature-programmed desorption of ammonia ( $\left.\mathrm{NH}_{3}-\mathrm{TPD}\right)$ analysis [36,194].

\section{Future Perspectives and Conclusions}

Glycerol, as a by-product generated in an immense amount from the transesterification used to produce biodiesel, must be used in an economical and environmentally friendly 
manner. To achieve this goal, various valorization technological routes have been developed including: (i) steam reforming of glycerol to produce $\mathrm{H}_{2}$ and syngas; (ii) dehydration of glycerol to produce acrolein; (iii) oxidation of glycerol to produce lactic acid; and (iv) selective hydrogenolysis of glycerol to produce either 1,3-propanediol or 1,2-propanediol. The research advances and main challenges of each of the above technological routes are summarized as follows:

i. For the steam reforming of glycerol, various noble-metals- and transition -metalsbased catalysts on various supports with or without a promoter have been investigated. Catalyst deactivation caused by coke deposition and sintering over time is unavoidable, which consequently leads to decreases in catalytic performance and product selectivity.

ii. Recently, intensified hybrid processes that consist of glycerol steam reforming and $\mathrm{CO}_{2}$ in situ removal have been explored including sorption-enhanced steam reforming, chemical looping steam reforming, and sorption-enhanced chemical looping steam reforming. To ensure the effectiveness of these technologies, new $\mathrm{CO}_{2}$ selective sorbents with better $\mathrm{CO}_{2}$ sorption efficiency and simplicity in sorbent regeneration must be developed.

iii. For transformation of glycerol to fine chemicals, a wide range of catalysts based on either noble and transition metals or bimetallic systems has been developed to promote glycerol conversion and selectivity toward acrolein, lactic acid, 1,3-propanediol, or 1,2-propanediol formation. Although some previous studies demonstrated the effectiveness of some heterogeneous catalysts, the catalyst deactivation caused by coke deposition, sintering, agglomeration, and leaching remains the main technical barrier that must be addressed in future research.

iv. To tackle this challenge, some novel reactor configurations have been designed to retard coke formation and the associated catalyst deactivation. For example, Gao et al. [38] developed a dual catalyst bed reactor for steam reforming of glycerol where $\mathrm{Cu} / \mathrm{SiO}_{2}$ is placed as the guard and $\mathrm{Ni} / \mathrm{SiO}_{2}$ is placed at the bottom to catalyze the reaction. Another instance of a new reactor design is using a membrane reactor in the steam reforming of glycerol over $\mathrm{Co}-\mathrm{Ni} / \mathrm{Al}_{2} \mathrm{O}_{3}$, as reported by Wang et al. [195]; however, it remains a necessity to design and develop efficient reactors not only for glycerol steam reforming but also for glycerol conversion to fine chemicals.

v. Another research gap that must be filled is that, until now, most studies on glycerol transformation into value-added chemicals were performed in a batch reactor system. Even though batch reactors can effectively illustrate the operational parameters for the process, experimental data from conducting the reaction in a continuous reactor are still required for process scale-up.

Author Contributions: Conceptualization, Y.H. and Q.H.; methodology, Y.H.; software, Y.H.; validation, Q.H. and C.X.; formal analysis, Y.H.; investigation, Y.H. and C.X.; resources, Y.H.; data curation, Y.H.; writing—original draft preparation, Y.H.; writing—review and editing, Q.H. and C.X.; visualization, Y.H.; supervision, Q.H. and C.X.; project administration, Q.H. and C.X.; funding acquisition, Q.H. and C.X. All authors have read and agreed to the published version of the manuscript.

Funding: This research received no external funding.

Data Availability Statement: Data is contained within the article.

Acknowledgments: The authors would like to acknowledge funding from the Natural Sciences and Engineering Research Council of Canada (NSERC) for Discovery Grants, and the Startup Fund from the University of Prince Edward Island.

Conflicts of Interest: The authors declared they have no conflict of interest. 


\section{References}

1. Ahmad, M.S.; Ab Rahim, M.H.; Alqahtani, T.M.; Witoon, T.; Lim, J.W.; Cheng, C.K. A review on advances in green treatment of glycerol waste with a focus on electro-oxidation pathway. Chemosphere 2021, 276, 130128. [CrossRef]

2. Jariah, N.F.; Hassan, M.A.; Taufiq-Yap, Y.H.; Roslan, A.M. Technological advancement for efficiency enhancement of biodiesel and residual glycerol refining: A mini review. Processes 2021, 9, 1198. [CrossRef]

3. Adhikari, S.; Fernando, S.D.; Haryanto, A. Hydrogen production from glycerin by steam reforming over nickel catalysts. Renew. Energy 2008, 33, 1097-1100. [CrossRef]

4. He, Q.; McNutt, J.; Yang, J. Utilization of the residual glycerol from biodiesel production for renewable energy generation. Renew. Sustain. Energy Rev. 2017, 71, 63-76. [CrossRef]

5. Katryniok, B.; Paul, S.; Bellière-Baca, V.; Rey, P.; Dumeignil, F. Glycerol dehydration to acrolein in the context of new uses of glycerol. Green Chem. 2010, 12, 2079-2098. [CrossRef]

6. Mamtani, K.; Shahbaz, K.; Farid, M.M. Glycerolysis of free fatty acids: A review. Renew. Sustain. Energy Rev. 2021, $137,110501$. [CrossRef]

7. Abomohra, A.E.F.; Elsayed, M.; Esakkimuthu, S.; El-Sheekh, M.; Hanelt, D. Potential of fat, oil and grease (FOG) for biodiesel production: A critical review on the recent progress and future perspectives. Prog. Energy Combust. Sci. 2020, 81, 100868. [CrossRef]

8. Basu, S.; Sen, A.K. A review on catalytic dehydration of glycerol to acetol. ChemBioEng Rev. 2021, 8, 1-22. [CrossRef]

9. Liu, S.; Yu, Z.; Wang, Y.; Sun, Z.; Liu, Y.; Shi, C.; Wang, A. Catalytic dehydration of glycerol to acrolein over unsupported MoP. Catal. Today 2021, 379, 132-140. [CrossRef]

10. Possato, L.G.; Acevedo, M.D.; Padró, C.L.; Briois, V.; Passos, A.R.; Pulcinelli, S.H.; Santilli, C.V.; Martins, L. Activation of Mo and V oxides supported on ZSM-5 zeolite catalysts followed by in situ XAS and XRD and their uses in oxydehydration of glycerol. Mol. Catal. 2020, 481, 110158. [CrossRef]

11. Mimura, N.; Muramatsu, N.; Hiyoshi, N.; Sato, O.; Yamaguchi, A. Continuous production of glyceric acid and lactic acid by catalytic oxidation of glycerol over an $\mathrm{Au}-\mathrm{Pt} / \mathrm{Al}_{2} \mathrm{O}_{3}$ bimetallic catalyst using a liquid-phase flow reactor. Catal. Today 2021, 375, 191-196. [CrossRef]

12. Xu, S.; Xiao, Y.; Zhang, W.; Liao, S.; Yang, R.; Li, J.; Hu, C. Relay catalysis of copper-magnesium catalyst on efficient valorization of glycerol to glycolic acid. Chem. Eng. J. 2022, 428, 132555. [CrossRef]

13. Schünemann, S.; Schüth, F.; Tüysüz, H. Selective glycerol oxidation over ordered mesoporous copper aluminum oxide catalysts. Catal. Sci. Technol. 2017, 7, 5614-5624. [CrossRef]

14. Vo, T.G.; Ho, P.Y.; Chiang, C.Y. Operando mechanistic studies of selective oxidation of glycerol to dihydroxyacetone over amorphous cobalt oxide. Appl. Catal. B Environ. 2022, 300, 120723. [CrossRef]

15. Yu, J.; Dappozze, F.; Martín-Gomez, J.; Hidalgo-Carrillo, J.; Marinas, A.; Vernoux, P.; Caravaca, A.; Guillard, C. Glyceraldehyde production by photocatalytic oxidation of glycerol on $\mathrm{WO}_{3}$-based materials. Appl. Catal. B Environ. 2021, 299, 120616. [CrossRef]

16. Sherbi, M.; Wesner, A.; Wisniewski, V.K.; Bukowski, A.; Velichkova, H.; Fiedler, B.; Albert, J. Superior CNT-supported bimetallic $\mathrm{RuCu}$ catalyst for the highly selective hydrogenolysis of glycerol to 1,2-propanediol. Catal. Sci. Technol. 2021, 11, 6649-6653. [CrossRef]

17. Cheng, S.; Fan, Y.; Zhang, X.; Zeng, Y.; Xie, S.; Pei, Y.; Zeng, G.; Qiao, M.; Zong, B. Tungsten-doped siliceous mesocellular foams-supported platinum catalyst for glycerol hydrogenolysis to 1,3-propanediol. Appl. Catal. B Environ. 2021, $297,120428$. [CrossRef]

18. Catalysts, B.N. Preparation of propanols by glycerol hydrogenolysis over bifunctional nickel-containing catalysts. Mol. Plant 2021, 26, 1565.

19. Li, H.; Dang, C.; Li, Y.; Yang, G.; Cao, Y.; Wang, H.; Peng, F.; Yu, H. Pt-calcium cobaltate enables sorption-enhanced steam reforming of glycerol coupled with chemical-looping $\mathrm{CH}_{4}$ combustion. Catal. Commun. 2008, 9, 2543-2546. [CrossRef]

20. Bozkurt, Ö.D.; Bağlar, N.; Çelebi, S.; Uzun, A. Screening of solid acid catalysts for etherification of glycerol with isobutene under identical conditions. Catal. Today 2020, 357, 483-494. [CrossRef]

21. Sánchez, G.; Gaikwad, V.; Holdsworth, C.; Dlugogorski, B.; Kennedy, E.; Stockenhuber, M. Catalytic conversion of glycerol to polymers in the presence of ammonia. Chem. Eng. J. 2016, 291, 279-286. [CrossRef]

22. Desgagnés, A.; Iliuta, M.C. Kinetic study of glycerol steam reforming catalyzed by a Ni-promoted metallurgical residue. Chem. Eng. J. 2022, 429, 10-12. [CrossRef]

23. Roslan, N.A.; Abidin, S.Z.; Ideris, A.; Vo, D.V.N. A review on glycerol reforming processes over Ni-based catalyst for hydrogen and syngas productions. Int. J. Hydrog. Energy 2020, 45, 18466-18489. [CrossRef]

24. Wang, J.; Yang, M.; Wang, A. Selective hydrogenolysis of glycerol to 1,3-propanediol over Pt-W based catalysts. Chin. J. Catal. 2020, 41, 1311-1319. [CrossRef]

25. Fokum, E.; Zabed, H.M.; Yun, J.; Zhang, G.; Qi, X. Recent technological and strategical developments in the biomanufacturing of 1,3-propanediol from glycerol. Int. J. Environ. Sci. Technol. 2021, 18, 2467-2490. [CrossRef]

26. Arcanjo, M.R.A.; da Silva, I.J., Jr.; Cavalcante, C.L., Jr.; Iglesias, J.; Morales, G.; Paniagua, M.; Melero, J.A.; Vieira, R.S. Glycerol valorization: Conversion to lactic acid by heterogeneous catalysis and separation by ion exchange chromatography. Biofuels Bioprod. Biorefin. 2020, 14, 357-370. [CrossRef] 
27. Smirnov, A.A.; Selishcheva, S.A.; Yakovlev, V.A. Acetalization catalysts for synthesis of valuable oxygenated fuel additives from glycerol. Catalysts 2018, 8, 595. [CrossRef]

28. Cornejo, A.; Barrio, I.; Campoy, M.; Lázaro, J.; Navarrete, B. Oxygenated fuel additives from glycerol valorization. Main production pathways and effects on fuel properties and engine performance: A critical review. Renew. Sustain. Energy Rev. 2017, 79, 1400-1413. [CrossRef]

29. Nanda, M.R.; Zhang, Y.; Yuan, Z.; Qin, W.; Ghaziaskar, H.S.; Xu, C. Catalytic conversion of glycerol for sustainable production of solketal as a fuel additive: A review. Renew. Sustain. Energy Rev. 2016, 56, 1022-1031. [CrossRef]

30. Galadima, A.; Muraza, O. A review on glycerol valorization to acrolein over solid acid catalysts. J. Taiwan Inst. Chem. Eng. 2016, 67, 29-44. [CrossRef]

31. Lin, Y.C. Catalytic valorization of glycerol to hydrogen and syngas. Int. J. Hydrog. Energy 2013, 38, 2678-2700. [CrossRef]

32. Macedo, M.S.; Soria, M.A.; Madeira, L.M. Process intensification for hydrogen production through glycerol steam reforming. Renew. Sustain. Energy Rev. 2021, 146, 111151. [CrossRef]

33. Ewan, B.C.R.; Allen, R.W.K. A figure of merit assessment of the routes to hydrogen. Int. J. Hydrog. Energy 2005, 30, 809-819. [CrossRef]

34. Alizadeh Sahraei, O.; Desgagnés, A.; Larachi, F.; Iliuta, M.C. Ni-Fe catalyst derived from mixed oxides Fe/Mg-bearing metallurgical waste for hydrogen production by steam reforming of biodiesel by-product: Investigation of catalyst synthesis parameters and temperature dependency of the reaction network. Appl. Catal. B Environ. 2020, 279, 119330. [CrossRef]

35. Gao, K.; Sahraei, O.A.; Iliuta, M.C. Development of residue coal fly ash supported nickel catalyst for $\mathrm{H}_{2}$ production via glycerol steam reforming. Appl. Catal. B Environ. 2021, 291, 119958. [CrossRef]

36. Qingli, X.; Zhengdong, Z.; Kai, H.; Shanzhi, X.; Chuang, M.; Chenge, C.; Huan, Y.; Yang, Y.; Yongjie, Y. Ni supported on MgO modified attapulgite as catalysts for hydrogen production from glycerol steam reforming. Int. J. Hydrog. Energy 2021, 46, 27380-27393. [CrossRef]

37. Li, S.; Zhang, J.; Zhu, B.; Wang, W. Stability and activity maintenance of Ni catalysts supported on La-, Ce-, and Mg-promoted $\mathrm{Al}_{2} \mathrm{O}_{3}$ and $\mathrm{ZrO}_{2}$ for $\mathrm{H}_{2}$ production from steam reforming of glycerol. Int. J. Energy Res. 2021, 45, 18304. [CrossRef]

38. Gao, Z.; Li, C.; Shao, Y.; Gao, G.; Xu, Q.; Tian, H.; Zhang, S.; Hu, X. Sequence of $\mathrm{Ni} / \mathrm{SiO}_{2}$ and $\mathrm{Cu} / \mathrm{SiO}_{2}$ in dual catalyst bed significantly impacts coke properties in glycerol steam reforming. Int. J. Hydrog. Energy 2021, 46, 26367-26380. [CrossRef]

39. Dou, B.; Zhao, L.; Zhang, H.; Wu, K.; Zhang, H. Renewable hydrogen production from chemical looping steam reforming of biodiesel byproduct glycerol by mesoporous oxygen carriers. Chem. Eng. J. 2021, 416, 127612. [CrossRef]

40. Moogi, S.; Nakka, L.; Potharaju, S.S.P.; Ahmed, A.; Farooq, A.; Jung, S.C.; Rhee, G.H.; Park, Y.K. Copper promoted Co/MgO: A stable and efficient catalyst for glycerol steam reforming. Int. J. Hydrog. Energy 2021, 46, 18073-18084. [CrossRef]

41. Omarov, S.O.; Sladkovskiy, D.A.; Martinson, K.D.; Peurla, M.; Aho, A.; Murzin, D.Y.; Popkov, V.I. Influence of the initial state of $\mathrm{ZrO}_{2}$ on genesis, activity and stability of $\mathrm{Ni} / \mathrm{ZrO}_{2}$ catalysts for steam reforming of glycerol. Appl. Catal. A Gen. 2021, 616, 118098. [CrossRef]

42. Moogi, S.; Lee, I.G.; Hwang, K.R. Catalytic steam reforming of glycerol over Ni- $\mathrm{La}_{2} \mathrm{O}_{3}-\mathrm{CeO}_{2} / \mathrm{SBA}-15$ catalyst for stable hydrogen-rich gas production. Int. J. Hydrog. Energy 2020, 45, 28462-28475. [CrossRef]

43. Menezes, J.P.d.S.Q.; Duarte, K.R.; Souza, M.M.V.M. Effect of magnesia addition in stability of cobalt catalysts supported on alumina for hydrogen generation by glycerol steam reforming. Catal. Lett. 2021, 151, 980-992. [CrossRef]

44. Dahdah, E.; Estephane, J.; Gennequin, C.; Aboukaïs, A.; Aouad, S.; Abi-Aad, E. Effect of La promotion on Ni/Mg-Al hydrotalcite derived catalysts for glycerol steam reforming. J. Environ. Chem. Eng. 2020, 8, 104228. [CrossRef]

45. Zhou, H.; Liu, S.; Jing, F.; Luo, S.Z.; Shen, J.; Pang, Y.; Chu, W. Synergetic bimetallic NiCo/CNT catalyst for hydrogen production by glycerol steam reforming: Effects of metal species distribution. Ind. Eng. Chem. Res. 2020, 59, 17259-17268. [CrossRef]

46. Kokumai, T.M.; Cantane, D.A.; Melo, G.T.; Paulucci, L.B.; Zanchet, D. $\mathrm{VO}_{\mathrm{x}}-\mathrm{Pt} / \mathrm{Al}_{2} \mathrm{O}_{3}$ catalysts for hydrogen production. Catal. Today 2017, 289, 249-257. [CrossRef]

47. Kotnala, S.; Singh, L.; Gahtori, J.; Tucker, C.; Kumar, A.; Van Steen, E.; Bordoloi, A. Steam reforming of glycerol for syngas production using Pt-Ni nanoparticles supported on bimodal porous $\mathrm{MgAl}_{2} \mathrm{O}_{4}$. Energy Fuels 2021, 35, 5217-5230. [CrossRef]

48. Charisiou, N.D.; Italiano, C.; Pino, L.; Sebastian, V.; Vita, A.; Goula, M.A. Hydrogen production via steam reforming of glycerol over $\mathrm{Rh} / \gamma-\mathrm{Al}_{2} \mathrm{O}_{3}$ catalysts modified with $\mathrm{CeO}_{2}, \mathrm{MgO}$ or $\mathrm{La}_{2} \mathrm{O}_{3}$. Renew. Energy 2020, 162, 908-925. [CrossRef]

49. Charisiou, N.D.; Siakavelas, G.I.; Papageridis, K.N.; Motta, D.; Dimitratos, N.; Sebastian, V.; Polychronopoulou, K.; Goula, M.A. The effect of noble metal (M: Ir, Pt, Pd) on $\mathrm{M} / \mathrm{Ce}_{2} \mathrm{O}_{3}-\gamma-\mathrm{Al}_{2} \mathrm{O}_{3}$ catalysts for hydrogen production via the steam reforming of glycerol. Catalysts 2020, 10, 790. [CrossRef]

50. Buffoni, I.N.; Gatti, M.N.; Santori, G.F.; Pompeo, F.; Nichio, N.N. Hydrogen from glycerol steam reforming with a platinum catalyst supported on a $\mathrm{SiO}_{2}-\mathrm{C}$ composite. Int. J. Hydrog. Energy 2017, 42, 12967-12977. [CrossRef]

51. Zarei Senseni, A.; Rezaei, M.; Meshkani, F. Glycerol steam reforming over noble metal nanocatalysts. Chem. Eng. Res. Des. 2017, 123, 360-366. [CrossRef]

52. Pastor-Pérez, L.; Sepúlveda-Escribano, A. Low temperature glycerol steam reforming on bimetallic PtSn/C catalysts: On the effect of the Sn content. Fuel 2017, 194, 222-228. [CrossRef]

53. Touri, A.E.; Taghizadeh, M. Hydrogen production via glycerol reforming over $\mathrm{Pt} / \mathrm{SiO}_{2}$ nanocatalyst in a spiral-shaped microchannel reactor. Int. J. Chem. React. Eng. 2016, 14, 1059-1068. [CrossRef] 
54. Alizadeh Sahraei, O.; Desgagnés, A.; Larachi, F.; Iliuta, M.C. A comparative study on the performance of M (Rh, Ru, Ni)-promoted metallurgical waste driven catalysts for $\mathrm{H}_{2}$ production by glycerol steam reforming. Int. J. Hydrog. Energy 2021, 46, 32017-32035. [CrossRef]

55. Silva, J.M.; Ribeiro, L.S.; Órfão, J.J.M.; Soria, M.A.; Madeira, L.M. Low temperature glycerol steam reforming over a Rh-based catalyst combined with oxidative regeneration. Int. J. Hydrog. Energy 2019, 44, 2461-2473. [CrossRef]

56. Demsash, H.D.; Kondamudi, K.V.K.; Upadhyayula, S.; Mohan, R. Ruthenium doped nickel-alumina-ceria catalyst in glycerol steam reforming. Fuel Process. Technol. 2018, 169, 150-156. [CrossRef]

57. Zarei Senseni, A.; Meshkani, F.; Seyed Fattahi, S.M.; Rezaei, M. A theoretical and experimental study of glycerol steam reforming over $\mathrm{Rh} / \mathrm{MgAl}_{2} \mathrm{O}_{4}$ catalysts. Energy Convers. Manag. 2017, 154, 127-137. [CrossRef]

58. Wang, Z.; Liu, L. Mesoporous silica supported phosphotungstic acid catalyst for glycerol dehydration to acrolein. Catal. Today 2021, 376, 55-64. [CrossRef]

59. Charisiou, N.D.; Papageridis, K.N.; Siakavelas, G.; Tzounis, L.; Kousi, K.; Baker, M.A.; Hinder, S.J.; Sebastian, V.; Polychronopoulou, K.; Goula, M.A. Glycerol steam reforming for hydrogen production over nickel supported on alumina, zirconia and silica catalysts. Top. Catal. 2017, 60, 1226-1250. [CrossRef]

60. Parlar Karakoc, O.; Kibar, M.E.; Akin, A.N.; Yildiz, M. Nickel-based catalysts for hydrogen production by steam reforming of glycerol. Int. J. Environ. Sci. Technol. 2019, 16, 5117-5124. [CrossRef]

61. Asedegbega-Nieto, E.; Guerrero-Ruíz, A.; Rodríguez-Ramos, I. Study of CO chemisorption on graphite-supported Ru-Cu and Ni-Cu bimetallic catalysts. Thermochim. Acta 2005, 434, 113-118. [CrossRef]

62. Chen, J.; Sun, J.; Wang, Y. Catalysts for steam reforming of bio-oil: A review. Ind. Eng. Chem. Res. 2017, 56, 4627-4637. [CrossRef]

63. Trimm, D.L. Thermal stability of catalyst supports. Stud. Surf. Sci. Catal. 1991, 68, $29-51$.

64. Wu, K.; Dou, B.; Zhang, H.; Liu, D.; Chen, H.; Xu, Y. Aqueous phase reforming of biodiesel byproduct glycerol over mesoporous $\mathrm{Ni}-\mathrm{Cu} / \mathrm{CeO}_{2}$ for renewable hydrogen production. Fuel 2022, 308, 122014. [CrossRef]

65. Sanchez, E.A.; Comelli, R.A. Hydrogen production by glycerol steam-reforming over nickel and nickel-cobalt impregnated on alumina. Int. J. Hydrog. Energy 2014, 39, 8650-8655. [CrossRef]

66. Sánchez, N.; Encinar, J.M.; Nogales, S.; González, J.F. Lanthanum effect on $\mathrm{Ni} / \mathrm{Al}_{2} \mathrm{O}_{3}$ as a catalyst applied in steam reforming of glycerol for hydrogen production. Processes 2019, 7, 449. [CrossRef]

67. Charisiou, N.D.; Papageridis, K.N.; Tzounis, L.; Sebastian, V.; Hinder, S.J.; Baker, M.A.; AlKetbi, M.; Polychronopoulou, K.; Goula, M.A. Ni supported on $\mathrm{CaO}-\mathrm{MgO}-\mathrm{Al}_{2} \mathrm{O}_{3}$ as a highly selective and stable catalyst for $\mathrm{H}_{2}$ production via the glycerol steam reforming reaction. Int. J. Hydrog. Energy 2019, 44, 256-273. [CrossRef]

68. Dobosz, J.; Cichy, M.; Zawadzki, M.; Borowiecki, T. Glycerol steam reforming over calcium hydroxyapatite supported cobalt and cobalt-cerium catalysts. J. Energy Chem. 2018, 27, 404-412. [CrossRef]

69. Menezes, J.P.d.S.Q.; Duarte, K.R.; Manfro, R.L.; Souza, M.M.V.M. Effect of niobia addition on cobalt catalysts supported on alumina for glycerol steam reforming. Renew. Energy 2020, 148, 864-875. [CrossRef]

70. Bossola, F.; Pereira-Hernández, X.I.; Evangelisti, C.; Wang, Y.; Dal Santo, V. Investigation of the promoting effect of Mn on a Pt/C catalyst for the steam and aqueous phase reforming of glycerol. J. Catal. 2017, 349, 75-83. [CrossRef]

71. Manfro, R.L.; Ribeiro, N.F.P.; Souza, M.M.V.M. Production of hydrogen from steam reforming of glycerol using nickel catalysts supported on $\mathrm{Al}_{2} \mathrm{O}_{3}, \mathrm{CeO}_{2}$ and $\mathrm{ZrO}_{2}$. Catal. Sustain. Energy 2013, 1, 60-70. [CrossRef]

72. Moraes, T.S.; Borges, L.E.P.; Farrauto, R.; Noronha, F.B. Steam reforming of ethanol on $\mathrm{Rh} / \mathrm{SiCeO}_{2}$ washcoated monolith catalyst: Stable catalyst performance. Int. J. Hydrog. Energy 2018, 43, 115-126. [CrossRef]

73. Shokrollahi Yancheshmeh, M.; Radfarnia, H.R.; Iliuta, M.C. High temperature $\mathrm{CO}_{2}$ sorbents and their application for hydrogen production by sorption enhanced steam reforming process. Chem. Eng. J. 2016, 283, 420-444. [CrossRef]

74. Dang, C.; Yang, W.; Zhou, J.; Cai, W. Porous Ni-Ca-Al-O bi-functional catalyst derived from layered double hydroxide intercalated with citrate anion for sorption-enhanced steam reforming of glycerol. Appl. Catal. B Environ. 2021, 298, 120547. [CrossRef]

75. Shokrollahi Yancheshmeh, M.; Iliuta, M.C. Embedding Ni in Ni-Al mixed-metal alkoxide for the synthesis of efficient coking resistant $\mathrm{Ni}-\mathrm{CaO}$-based catalyst-sorbent bifunctional materials for sorption-enhanced steam reforming of glycerol. ACS Sustain. Chem. Eng. 2020, 8, 16746-16756. [CrossRef]

76. Dang, C.; Liu, L.; Yang, G.; Cai, W.; Long, J.; Yu, H. Mg-promoted Ni-CaO microsphere as bi-functional catalyst for hydrogen production from sorption-enhanced steam reforming of glycerol. Chem. Eng. J. 2020, 383, 123204. [CrossRef]

77. Ji, G.; Yao, J.G.; Clough, P.T.; Da Costa, J.C.D.; Anthony, E.J.; Fennell, P.S.; Wang, W.; Zhao, M. Enhanced hydrogen production from thermochemical processes. Energy Environ. Sci. 2018, 11, 2647-2672. [CrossRef]

78. Wang, Y.; Memon, M.Z.; Seelro, M.A.; Fu, W.; Gao, Y.; Dong, Y.; Ji, G. A review of $\mathrm{CO}_{2}$ sorbents for promoting hydrogen production in the sorption-enhanced steam reforming process. Int. J. Hydrog. Energy 2021, 46, 23358-23379. [CrossRef]

79. Dou, B.; Song, Y.; Wang, C.; Chen, H.; Xu, Y. Hydrogen production from catalytic steam reforming of biodiesel byproduct glycerol: Issues and challenges. Renew. Sustain. Energy Rev. 2014, 30, 950-960. [CrossRef]

80. Jiang, B.; Li, L.; Zhang, Q.; Ma, J.; Zhang, H.; Bai, J.; Bian, Z.; Dou, B.; Kawi, S.; Tang, D. Chemical looping reforming of glycerol for continuous $\mathrm{H}_{2}$ production by moving-bed reactors: Simulation and experiment. Energy Fuels 2020, 34, 1841-1850. [CrossRef]

81. Dou, B.; Song, Y.; Wang, C.; Chen, H.; Yang, M.; Xu, Y. Hydrogen production by enhanced-sorption chemical looping steam reforming of glycerol in moving-bed reactors. Appl. Energy 2014, 130, 342-349. [CrossRef] 
82. Jiang, B.; Dou, B.; Wang, K.; Song, Y.; Chen, H.; Zhang, C.; Xu, Y.; Li, M. Hydrogen production from chemical looping steam reforming of glycerol by Ni based Al-MCM-41 oxygen carriers in a fixed-bed reactor. Fuel 2016, 183, 170-176. [CrossRef]

83. Jiang, B.; Dou, B.; Song, Y.; Zhang, C.; Du, B.; Chen, H.; Wang, C.; Xu, Y. Hydrogen production from chemical looping steam reforming of glycerol by Ni-based oxygen carrier in a fixed-bed reactor. Chem. Eng. J. 2015, 280, 459-467. [CrossRef]

84. Karimi, E.; Forutan, H.R.; Saidi, M.; Rahimpour, M.R.; Shariati, A. Experimental study of chemical-looping reforming in a fixed-bed reactor: Performance investigation of different oxygen carriers on $\mathrm{Al}_{2} \mathrm{O}_{3}$ and $\mathrm{TiO}_{2}$ support. Energy Fuels 2014, 28, 2811-2820. [CrossRef]

85. Rydén, M.; Ramos, P. $\mathrm{H}_{2}$ production with $\mathrm{CO}_{2}$ capture by sorption enhanced chemical-looping reforming using $\mathrm{NiO}$ as oxygen carrier and $\mathrm{CaO}$ as $\mathrm{CO}_{2}$ sorbent. Fuel Process. Technol. 2012, 96, 27-36. [CrossRef]

86. Belousov, A.S. Tuning of selectivity for sustainable production of acrolein from glycerol. ChemistrySelect 2021, 6, 9191-9198. [CrossRef]

87. Wang, Y.; Xiao, Y.; Xiao, G. Sustainable value-added $\mathrm{C}_{3}$ chemicals from glycerol transformations: A mini review for heterogenous catalytic processes. Chin. J. Chem. Eng. 2019, 27, 1536-1542. [CrossRef]

88. Fernandes, J.O.; Neves, T.M.; da Silva, E.D.; da Rosa, C.A.; Mortola, V.B. Influence of reaction parameters on glycerol dehydration over HZSM-5 catalyst. React. Kinet. Mech. Catal. 2021, 132, 485-498. [CrossRef]

89. Kraleva, E.; Atia, H. Keggin-type heteropolyacids supported on sol-gel oxides as catalysts for the dehydration of glycerol to acrolein. React. Kinet. Mech. Catal. 2019, 126, 103-117. [CrossRef]

90. Nadji, L.; Massó, A.; Delgado, D.; Issaadi, R.; Rodriguez-Aguado, E.; Rodriguez-Castellón, E.; López Nieto, J.M. Gas phase dehydration of glycerol to acrolein over WO3-based catalysts prepared by non-hydrolytic sol-gel synthesis. RSC Adv. 2018, 8, 13344-13352. [CrossRef]

91. Talebian-Kiakalaieh, A.; Amin, N.A.S.; Hezaveh, H. Glycerol for renewable acrolein production by catalytic dehydration. Renew. Sustain. Energy Rev. 2014, 40, 28-59. [CrossRef]

92. Corma, A.; Huber, G.W.; Sauvanaud, L.; O'Connor, P. Biomass to chemicals: Catalytic conversion of glycerol/water mixtures into acrolein, reaction network. J. Catal. 2008, 257, 163-171. [CrossRef]

93. Viswanadham, B.; Vishwanathan, V.; Chary, K.V.R.; Satyanarayana, Y. Catalytic dehydration of glycerol to acrolein over mesoporous MCM-41 supported heteropolyacid catalysts. J. Porous Mater. 2021, 28, 1269-1279. [CrossRef]

94. Pala-Rosas, I.; Contreras, J.L.; Salmones, J.; Zeifert, B.; López-Medina, R.; Navarrete-Bolaños, J.; Hernández-Ramírez, S.; PérezCabrera, J.; Fragoso-Montes De Oca, A.A. Catalytic deactivation of HY zeolites in the dehydration of glycerol to acrolein. Catalysts 2021, 11, 360. [CrossRef]

95. Ginjupalli, S.; Balla, P.; Shaik, H.; Nekkala, N.; Ponnala, B.; Mitta, H. Comparative study of vapour phase glycerol dehydration over different tungstated metal phosphate acid catalysts. New J. Chem. 2019, 43, 16860-16869. [CrossRef]

96. Xie, Q.; Li, S.; Gong, R.; Zheng, G.; Wang, Y.; Xu, P.; Duan, Y.; Yu, S.; Lu, M.; Ji, W.; et al. Microwave-assisted catalytic dehydration of glycerol for sustainable production of acrolein over a microwave absorbing catalyst. Appl. Catal. B Environ. 2019, 243, 455-462 [CrossRef]

97. Li, X.; Huang, L.; Kochubei, A.; Huang, J.; Shen, W.; Xu, H.; Li, Q. Evolution of a metal-organic framework into a brønsted acid catalyst for glycerol dehydration to acrolein. ChemSusChem 2020, 13, 5073-5079. [CrossRef]

98. Zhao, S.; Wang, W.D.; Wang, L.; Wang, W.; Huang, J. Cooperation of hierarchical pores with strong Brønsted acid sites on SAPO-34 catalysts for the glycerol dehydration to acrolein. J. Catal. 2020, 389, 166-175. [CrossRef]

99. Belousov, A.S.; Esipovich, A.L.; Otopkova, K.V.; Kanakov, E.A.; Uvarova, V.D.; Shishulina, A.V.; Vorotyntsev, A.V. Gas-phase dehydration of glycerol into acrolein in the presence of polyoxometalates. Kinet. Catal. 2020, 61, 595-602. [CrossRef]

100. Ali, B.; Lan, X.; Arslan, M.T.; Gilani, S.Z.A.; Wang, H.; Wang, T. Controlling the selectivity and deactivation of H-ZSM-5 by tuning b-axis channel length for glycerol dehydration to acrolein. J. Ind. Eng. Chem. 2020, 88, 127-136. [CrossRef]

101. Ma, T.; Ding, J.; Liu, X.; Chen, G.; Zheng, J. Gas-phase dehydration of glycerol to acrolein over different metal phosphate catalysts. Korean J. Chem. Eng. 2020, 37, 955-960. [CrossRef]

102. Wang, X.; Zhao, F.; Huang, L. Low temperature dehydration of glycerol to acrolein in vapor phase with hydrogen as dilution: From catalyst screening via TPSR to real-time reaction in a fixed-bed. Catalysts 2020, 10, 43. [CrossRef]

103. Ren, X.; Zhang, F.; Sudhakar, M.; Wang, N.; Dai, J.; Liu, L. Gas-phase dehydration of glycerol to acrolein catalyzed by hybrid acid sites derived from transition metal hydrogen phosphate and meso-HZSM-5. Catal. Today 2019, 332, 20-27. [CrossRef]

104. Han, Q.; Ge, J.; Yang, Y.; Liu, B. Nickel substituted tungstophosphoric acid supported on Y-ASA composites as catalysts for the dehydration of gas-phase glycerol to acrolein. React. Kinet. Mech. Catal. 2019, 127, 331-343. [CrossRef]

105. Diallo, M.M.; Laforge, S.; Pouilloux, Y.; Mijoin, J. Influence of the preparation procedure and crystallite size of Fe-MFI zeolites in the oxidehydration of glycerol to acrolein and acrylic acid. Catal. Commun. 2019, 126, 21-25. [CrossRef]

106. Shan, J.; Li, Z.; Zhu, S.; Liu, H.; Li, J.; Wang, J.; Fan, W. Nanosheet MFI zeolites for gas phase glycerol dehydration to acrolein. Catalysts 2019, 9, 121. [CrossRef]

107. Torres, S.; Palacio, R.; López, D. Support effect in $\mathrm{Co}_{3} \mathrm{O}_{4}$-based catalysts for selective partial oxidation of glycerol to lactic acid. Appl. Catal. A Gen. 2021, 621, 118199. [CrossRef]

108. Chai, S.H.; Wang, H.P.; Liang, Y.; Xu, B.Q. Sustainable production of acrolein: Investigation of solid acid-base catalysts for gas-phase dehydration of glycerol. Green Chem. 2007, 9, 1130-1136. [CrossRef] 
109. Kim, Y.T.; Jung, K.D.; Park, E.D. Gas-phase dehydration of glycerol over silica-alumina catalysts. Appl. Catal. B Environ. 2011, 107, 177-187. [CrossRef]

110. Alhanash, A.; Kozhevnikova, E.F.; Kozhevnikov, I.V. Gas-phase dehydration of glycerol to acrolein catalysed by caesium heteropoly salt. Appl. Catal. A Gen. 2010, 378, 11-18. [CrossRef]

111. Zhang, H.; Hu, Z.; Huang, L.; Zhang, H.; Song, K.; Wang, L.; Shi, Z.; Ma, J.; Zhuang, Y.; Shen, W.; et al. Dehydration of glycerol to acrolein over hierarchical ZSM-5 zeolites: Effects of mesoporosity and acidity. ACS Catal. 2015, 5, 2548-2558. [CrossRef]

112. Monson, P.A. Contact angles, pore condensation, and hysteresis: Insights from a simple molecular model. Adsorpt. J. Int. Adsorpt. Soc. 2008, 12295-12302. [CrossRef] [PubMed]

113. Jiang, X.C.; Zhou, C.H.; Tesser, R.; Di Serio, M.; Tong, D.S.; Zhang, J.R. Coking of catalysts in catalytic glycerol dehydration to acrolein. Ind. Eng. Chem. Res. 2018, 57, 10736-10753. [CrossRef]

114. Trakarnpruk, W. Platinum/phosphotungstic acid/(Zr)MCM-41 catalysts in glycerol dehydration. Mendeleev Commun. 2014, 24, 167-169. [CrossRef]

115. Ma, T.; Yun, Z.; Xu, W.; Chen, L.; Li, L.; Ding, J.; Shao, R. Pd- $\mathrm{H}_{3} \mathrm{PW}_{12} \mathrm{O}_{40} / \mathrm{Zr}-\mathrm{MCM}-41$ : An efficient catalyst for the sustainable dehydration of glycerol to acrolein. Chem. Eng. J. 2016, 294, 343-352. [CrossRef]

116. Dalil, M.; Carnevali, D.; Dubois, J.L.; Patience, G.S. Transient acrolein selectivity and carbon deposition study of glycerol dehydration over $\mathrm{WO}_{3} / \mathrm{TiO}_{2}$ catalyst. Chem. Eng. J. 2015, 270, 557-563. [CrossRef]

117. Singh, R.; Gbordzoe, E. Modeling FCC spent catalyst regeneration with computational fluid dynamics. Powder Technol. 2017, 316, 560-568. [CrossRef]

118. Katryniok, B.; Meléndez, R.; Bellière-Baca, V.; Rey, P.; Dumeignil, F.; Fatah, N.; Paul, S. Catalytic dehydration of glycerol to acrolein in a two-zone fluidized bed reactor. Front. Chem. 2019, 7, 127. [CrossRef]

119. Razali, N.; Abdullah, A.Z. Production of lactic acid from glycerol via chemical conversion using solid catalyst: A review. Appl. Catal. A Gen. 2017, 543, 234-246. [CrossRef]

120. Diguilio, E.; Renzini, M.S.; Pierella, L.B.; Domine, M.E. Conversion of glycerol to value added products in a semi-continuous batch reactor using noble metals supported on ZSM-11 zeolite. Nanomaterials 2021, 11, 510. [CrossRef]

121. Arcanjo, M.R.A.; Paniagua, M.; Morales, G.; Iglesias, J.; Melero, J.; Da Silva, I.; Rodríguez-Castellón, E.; Vieira, R.S. Temperature effect on pretreatment of the activated carbon support (Pt/AC and Pd/AC) for glycerin into lactic acid. Ind. Eng. Chem. Res. 2020, 59, 14643-14657. [CrossRef]

122. Sever, B.; Yildiz, M. Conversion of glycerol to lactic acid over Au/bentonite catalysts in alkaline solution. React. Kinet. Mech. Catal. 2020, 130, 863-874. [CrossRef]

123. Douthwaite, M.; Powell, N.; Taylor, A.; Ford, G.; López, J.M.; Solsona, B.; Yang, N.; Sanahuja-Parejo, O.; He, Q.; Morgan, D.J.; et al. Glycerols selective oxidation to lactic acid over AuPt nanoparticles; enhancing reaction selectivity and understanding by support modification. ChemCatChem 2020, 12, 3097-3107. [CrossRef]

124. Evans, C.D.; Douthwaite, M.; Carter, J.H.; Pattisson, S.; Kondrat, S.A.; Bethell, D.; Knight, D.W.; Taylor, S.H.; Hutchings, G.J. Enhancing the understanding of the glycerol to lactic acid reaction mechanism over $\mathrm{AuPt} / \mathrm{TiO}_{2}$ under alkaline conditions. J. Chem. Phys. 2020, 152, 134705. [CrossRef] [PubMed]

125. Xiu, Z.; Wang, H.; Cai, C.; Li, C.; Yan, L.; Wang, C.; Li, W.; Xin, H.; Zhu, C.; Zhang, Q.; et al. Ultrafast glycerol conversion to lactic acid over magnetically recoverable Ni-NiO x@C catalysts. Ind. Eng. Chem. Res. 2020, 59, 9912-9925. [CrossRef]

126. Diguilio, E.; Galarza, E.D.; Domine, M.E.; Pierella, L.B.; Renzini, M.S. Tuning product selectivity in the catalytic oxidation of glycerol by employing metal-ZSM-11 materials. New J. Chem. 2020, 44, 4363-4375. [CrossRef]

127. Saleh, S.N.M.; Abdullah, A.Z. Zirconium-cerium oxides supported on SBA-15 as catalyst for shape-selective synthesis of lactic acid from glycerol. Waste Biomass Valorization 2021, 12, 2565-2578. [CrossRef]

128. Shen, L.; Yu, Z.; Zhang, D.; Yin, H.; Wang, C.; Wang, A. Glycerol valorization to lactic acid catalyzed by hydroxyapatite-supported palladium particles. J. Chem. Technol. Biotechnol. 2019, 94, 204-215. [CrossRef]

129. Saelee, T.; Limsoonthakul, P.; Aphichoksiri, P.; Rittiruam, M.; Lerdpongsiripaisarn, M.; Miyake, T.; Yamashita, H.; Mori, K.; Kuwahara, Y.; Praserthdam, S.; et al. Experimental and computational study on roles of $\mathrm{WO}_{\mathrm{x}}$ promoting strong metal support promoter interaction in Pt catalysts during glycerol hydrogenolysis. Sci. Rep. 2021, 11, 1-12. [CrossRef]

130. Zhang, C.; Wang, T.; Liu, X.; Ding, Y. Selective oxidation of glycerol to lactic acid over activated carbon supported Pt catalyst in alkaline solution. Cuihua Xuebao/Chin. J. Catal. 2016, 37, 502-509. [CrossRef]

131. Yang, G.Y.; Ke, Y.H.; Ren, H.F.; Liu, C.L.; Yang, R.Z.; Dong, W.S. The conversion of glycerol to lactic acid catalyzed by $\mathrm{ZrO}_{2}-$ supported $\mathrm{CuO}$ catalysts. Chem. Eng. J. 2016, 283, 759-767. [CrossRef]

132. Yin, H.; Zhang, C.; Yin, H.; Gao, D.; Shen, L.; Wang, A. Hydrothermal conversion of glycerol to lactic acid catalyzed by $\mathrm{Cu}$ /hydroxyapatite, $\mathrm{Cu} / \mathrm{MgO}$, and $\mathrm{Cu} / \mathrm{ZrO}_{2}$ and reaction kinetics. Chem. Eng. J. 2016, 288, 332-343. [CrossRef]

133. Feng, S.; Takahashi, K.; Miura, H.; Shishido, T. One-pot synthesis of lactic acid from glycerol over a Pt/L-Nb $2 \mathrm{O}_{5}$ catalyst under base-free conditions. Fuel Process. Technol. 2020, 197, 106202. [CrossRef]

134. Marques, F.L.; Oliveira, A.C.; Filho, J.M.; Rodríguez-Castellón, E.; Cavalcante, C.L.; Vieira, R.S. Synthesis of lactic acid from glycerol using a Pd/C catalyst. Fuel Process. Technol. 2015, 138, 228-235. [CrossRef]

135. Dai, C.; Sun, L.; Liao, H.; Khezri, B.; Webster, R.D.; Fisher, A.C.; Xu, Z.J. Electrochemical production of lactic acid from glycerol oxidation catalyzed by AuPt nanoparticles. J. Catal. 2017, 356, 14-21. [CrossRef] 
136. Sarangapany, S.; Mohanty, K. Facile green synthesis of magnetically separable Au-Pt@TiO $\mathrm{T}_{2}$ nanocomposite for efficient catalytic reduction of organic pollutants and selective oxidation of glycerol. J. Alloys Compd. 2020, 830, 154636. [CrossRef]

137. Purushothaman, R.K.P.; van Haveren, J.; van Es, D.S.; Melián-Cabrera, I.; Meeldijk, J.D.; Heeres, H.J. An efficient one pot conversion of glycerol to lactic acid using bimetallic gold-platinum catalysts on a nanocrystalline $\mathrm{CeO}_{2}$ support. Appl. Catal. $B$ Environ. 2014, 147, 92-100. [CrossRef]

138. Zhang, M.; Shi, J.; Sun, Y.; Ning, W.; Hou, Z. Selective oxidation of glycerol over nitrogen-doped carbon nanotubes supported platinum catalyst in base-free solution. Catal. Commun. 2015, 70, 72-76. [CrossRef]

139. Saxena, R.K.; Anand, P.; Saran, S.; Isar, J. Microbial production of 1,3-propanediol: Recent developments and emerging opportunities. Biotechnol. Adv. 2009, 27, 895-913. [CrossRef]

140. Wang, B.; Liu, F.; Guan, W.; Wang, A.; Zhang, T. Promoting the effect of Au on the selective hydrogenolysis of glycerol to 1,3-propanediol over the $\mathrm{Pt} / \mathrm{WO}_{\mathrm{x}} / \mathrm{Al}_{2} \mathrm{O}_{3}$ catalyst. ACS Sustain. Chem. Eng. 2021, 9, 5705-5715. [CrossRef]

141. Wu, F.; Jiang, H.; Zhu, X.; Lu, R.; Shi, L.; Lu, F. Effect of tungsten species on selective hydrogenolysis of glycerol to 1,3-propanediol. ChemSusChem 2021, 14, 569-581. [CrossRef] [PubMed]

142. Da Silva Ruy, A.D.; de Brito Alves, R.M.; Reis Hewer, T.L.; de Aguiar Pontes, D.; Gomes Teixeira, L.S.; Magalhães Pontes, L.A. Catalysts for glycerol hydrogenolysis to 1,3-propanediol: A review of chemical routes and market. Catal. Today 2021, 381, 243-253. [CrossRef]

143. Xu, W.; Niu, P.; Guo, H.; Jia, L.; Li, D. Hydrogenolysis of glycerol to 1,3-propanediol over a Al2O3-supported platinum tungsten catalyst with two-dimensional open structure. React. Kinet. Mech. Catal. 2021, 133, 173-189. [CrossRef]

144. Edake, M.; Dalil, M.; Darabi Mahboub, M.J.; Dubois, J.L.; Patience, G.S. Catalytic glycerol hydrogenolysis to 1,3-propanediol in a gas-solid fluidized bed. RSC Adv. 2017, 7, 3853-3860. [CrossRef]

145. Zhu, S.; Gao, X.; Zhu, Y.; Li, Y. Promoting effect of WOx on selective hydrogenolysis of glycerol to 1,3-propanediol over bifunctional Pt-WOx $/ \mathrm{Al}_{2} \mathrm{O}_{3}$ catalysts. J. Mol. Catal. A Chem. 2015, 398, 391-398. [CrossRef]

146. Shi, G.; Cao, Z.; Xu, J.; Jin, K.; Bao, Y.; Xu, S. Effect of $\mathrm{WO}_{\mathrm{x}}$ doping into $\mathrm{Pt} / \mathrm{SiO}_{2}$ catalysts for glycerol hydrogenolysis to 1,3-propanediol in liquid phase. Catal. Lett. 2018, 148, 2304-2314. [CrossRef]

147. Zhu, S.; Gao, X.; Zhu, Y.; Zhu, Y.; Xiang, X.; Hu, C.; Li, Y. Alkaline metals modified Pt- $\mathrm{H}_{4} \mathrm{SiW}_{2} \mathrm{O}_{40} / \mathrm{ZrO}_{2}$ catalysts for the selective hydrogenolysis of glycerol to 1,3-propanediol. Appl. Catal. B Environ. 2013, 140-141, 60-67. [CrossRef]

148. Yang, C.; Zhang, F.; Lei, N.; Yang, M.; Liu, F.; Miao, Z.; Sun, Y.; Zhao, X.; Wang, A. Understanding the promotional effect of Au on $\mathrm{Pt} / \mathrm{WO} 3$ in hydrogenolysis of glycerol to 1,3-propanediol. Cuihua Xuebao/Chin. J. Catal. 2018, 39, 1366-1372. [CrossRef]

149. Priya, S.S.; Kumar, V.P.; Kantam, M.L.; Bhargava, S.K.; Chary, K.V.R. Vapour-phase hydrogenolysis of glycerol to 1,3-propanediol over supported pt catalysts: The effect of supports on the catalytic functionalities. Catal. Lett. 2014, 144, 2129-2143. [CrossRef]

150. Priya, S.S.; Kumar, V.P.; Kantam, M.L.; Bhargava, S.K.; Srikanth, A.; Chary, K.V.R. High efficiency conversion of glycerol to 1,3-propanediol using a novel platinum-tungsten catalyst supported on SBA-15. Ind. Eng. Chem. Res. 2015, 54, 9104-9115. [CrossRef]

151. Arundhathi, R.; Mizugaki, T.; Mitsudome, T.; Jitsukawa, K.; Kaneda, K. Highly selective hydrogenolysis of glycerol to 1,3propanediol over a boehmite-supported platinum/tungsten catalyst. ChemSusChem 2013, 6, 1345-1347. [CrossRef] [PubMed]

152. Zhou, Z.; Jia, H.; Guo, Y.; Wang, Y.; Liu, X.; Xia, Q.; Li, X.; Wang, Y. The promotional effect of sulfates on $\mathrm{TiO}_{2}$ supported Pt-WOX catalyst for hydrogenolysis of glycerol. ChemCatChem 2021, 13, 3953-3959. [CrossRef]

153. Chanklang, S.; Mondach, W.; Somchuea, P.; Witoon, T.; Chareonpanich, M.; Faungnawakij, K.; Seubsai, A. Hydrogenolysis of glycerol to 1,3-propanediol over H-ZSM-5-supported iridium and rhenium oxide catalysts. Catal. Today 2021, 1-9. [CrossRef]

154. Liu, L.; Kawakami, S.; Nakagawa, Y.; Tamura, M.; Tomishige, K. Highly active iridium-rhenium catalyst condensed on silica support for hydrogenolysis of glycerol to 1,3-propanediol. Appl. Catal. B Environ. 2019, 256, 117775. [CrossRef]

155. Wan, X.; Zhang, Q.; Zhu, M.; Zhao, Y.; Liu, Y.; Zhou, C.; Yang, Y.; Cao, Y. Interface synergy between IrOx and H-ZSM-5 in selective C-O hydrogenolysis of glycerol toward 1,3-propanediol. J. Catal. 2019, 375, 339-350. [CrossRef]

156. Varghese, J.J.; Cao, L.; Robertson, C.; Yang, Y.; Gladden, L.F.; Lapkin, A.A.; Mushrif, S.H. Synergistic contribution of the acidic mMetal oxide-metal couple and solvent environment in the selective hydrogenolysis of glycerol: A combined experimental and computational study using $\mathrm{ReO}_{\mathrm{x}}-\mathrm{Ir}$ as the catalyst. ACS Catal. 2019, 9, 485-503. [CrossRef]

157. Deng, C.; Duan, X.; Zhou, J.; Zhou, X.; Yuan, W.; Scott, S.L. Ir-Re alloy as a highly active catalyst for the hydrogenolysis of glycerol to 1,3-propanediol. Catal. Sci. Technol. 2015, 5, 1540-1547. [CrossRef]

158. Syuhada, A.; Ameen, M.; Azizan, M.T.; Aqsha, A.; Yusoff, M.H.M.; Ramli, A.; Alnarabiji, M.S.; Sher, F. In-situ hydrogenolysis of glycerol using hydrogen produced via aqueous phase reforming of glycerol over sonochemically synthesized nickel-based nano-catalyst. Mol. Catal. 2021, 514, 111860. [CrossRef]

159. Zhou, W.; Li, Y.; Wang, X.; Yao, D.; Wang, Y.; Huang, S.; Li, W.; Zhao, Y.; Wang, S.; Ma, X. Insight into the nature of Brönsted acidity of Pt-( $\left.\mathrm{WO}_{x}\right) \mathrm{n}-\mathrm{H}$ model catalysts in glycerol hydrogenolysis. J. Catal. 2020, 388, 154-163. [CrossRef]

160. Liang, Y.; Shi, G.; Jin, K. Promotion effect of $\mathrm{Al}_{2} \mathrm{O}_{3}$ on Pt- $\mathrm{WO}_{\mathrm{x}} / \mathrm{SiO}_{2}$ catalysts for selective hydrogenolysis of bioglycerol to 1,3-propanediol in liquid phase. Catal. Lett. 2020, 150, 2365-2376. [CrossRef]

161. Xi, Z.; Hong, Z.; Huang, F.; Zhu, Z.; Jia, W.; Li, J. Hydrogenolysis of glycerol on the $\mathrm{ZrO}_{2}-\mathrm{TiO}_{2}$ supported Pt-WO catalyst. Catalysts 2020, 10, 312. [CrossRef]

162. Shi, G.; Xu, J.; Song, Z.; Cao, Z.; Jin, K.; Xu, S.; Yan, X. Selective hydrogenolysis of glycerol to 1,3-propanediol over Pt-WO $/$ /SAPO34 catalysts. Mol. Catal. 2018, 456, 22-30. [CrossRef] 
163. Salgado, A.L.P.; Araújo, F.C.; Soares, A.V.H.; Xing, Y.; Passos, F.B. Glycerol hydrogenolysis over Ru-Cu bimetallic catalysts supported on modified zirconias. Appl. Catal. A Gen. 2021, 626, 118359. [CrossRef]

164. Zhao, H.; Zheng, L.; Li, X.; Chen, P.; Hou, Z. Hydrogenolysis of glycerol to 1,2-propanediol over Cu-based catalysts: A short review. Catal. Today 2020, 355, 84-95. [CrossRef]

165. Oberhauser, W.; Evangelisti, C.; Jumde, R.P.; Psaro, R.; Vizza, F.; Bevilacqua, M.; Filippi, J.; Machado, B.F.; Serp, P. Platinum on carbonaceous supports for glycerol hydrogenolysis: Support effect. J. Catal. 2015, 325, 111-117. [CrossRef]

166. Silveira, F.J.L.; Moreira, C.R.; Grecy, I.D.B.; Gaspar, A.B. Activated Carbon from renewable sugarcane straw: Support for Ru catalyst in glycerol hydrogenolysis to 1,2 propanodiol, ethyleneglycol and propanols. ChemistrySelect 2020, 5, 13376-13386. [CrossRef]

167. Wu, Z.; Mao, Y.; Wang, X.; Zhang, M. Preparation of a Cu-Ru/carbon nanotube catalyst for hydrogenolysis of glycerol to 1,2-propanediol via hydrogen spillover. Green Chem. 2011, 13, 1311-1316. [CrossRef]

168. Nakagawa, Y.; Tomishige, K. Heterogeneous catalysis of the glycerol hydrogenolysis. Catal. Sci. Technol. 2011, 1, 179-190. [CrossRef]

169. Mauriello, F.; Ariga, H.; Musolino, M.G.; Pietropaolo, R.; Takakusagi, S.; Asakura, K. Exploring the catalytic properties of supported palladium catalysts in the transfer hydrogenolysis of glycerol. Appl. Catal. B Environ. 2015, 166-167, 121-131. [CrossRef]

170. Azri, N.; Irmawati, R.; Nda-Umar, U.I.; Saiman, M.I.; Taufiq-Yap, Y.H. Promotional effect of transition metals (Cu, Ni, Co, Fe, Zn)-supported on dolomite for hydrogenolysis of glycerol into 1,2-propanediol. Arab. J. Chem. 2021, 14, 103047. [CrossRef]

171. Mishra, N.K.; Kumar, P.; Srivastava, V.C.; Stangar, U.L. Synthesis of Cu-based catalysts for hydrogenolysis of glycerol to 1,2-propanediol with in-situ generated hydrogen. J. Environ. Chem. Eng. 2021, 9, 1-7. [CrossRef]

172. Li, X.; Wu, D. Synthesis of Co-doped micro-mesoporous SAPO-11 zeolite for glycerol hydrogenolysis. Korean J. Chem. Eng. 2020, 37, 216-223. [CrossRef]

173. Mitta, H.; Devunuri, N.; Sunkari, J.; Mutyala, S.; Balla, P.; Perupogu, V. A highly active dispersed copper oxide phase on calcined $\mathrm{Mg}_{9} \mathrm{Al}_{2.7}-\mathrm{Ga}_{2.3} \mathrm{O}_{2}$ catalysts in glycerol hydrogenolysis. Catal. Today 2021, 375, 204-215. [CrossRef]

174. Shan, J.; Liu, H.; Lu, K.; Zhu, S.; Li, J.; Wang, J.; Fan, W. Identification of the dehydration active sites in glycerol hydrogenolysis to 1,2-propanediol over $\mathrm{Cu} / \mathrm{SiO}_{2}$ catalysts. J. Catal. 2020, 383, 13-23. [CrossRef]

175. De Andrade, T.S.; Souza, M.M.V.M.; Manfro, R.L. Hydrogenolysis of glycerol to 1,2-propanediol without external $\mathrm{H}_{2}$ addition in alkaline medium using Ni-Cu catalysts supported on Y zeolite. Renew. Energy 2020, 160, 919-930. [CrossRef]

176. Wang, C.; Jiang, H.; Chen, C.; Chen, R.; Xing, W. Solvent effect on hydrogenolysis of glycerol to 1,2-propanediol over Cu-ZnO catalyst. Chem. Eng. J. 2015, 264, 344-350. [CrossRef]

177. Zhou, C.H.; Deng, K.; Di Serio, M.; Xiao, S.; Tong, D.S.; Li, L.; Lin, C.X.; Beltramini, J.; Zhang, H.; Yu, W.H. Cleaner hydrothermal hydrogenolysis of glycerol to 1,2-propanediol over $\mathrm{Cu}$ / oxide catalysts without addition of external hydrogen. Mol. Catal. 2017, 432, 274-284. [CrossRef]

178. Wu, Z.; Mao, Y.; Song, M.; Yin, X.; Zhang, M. Cu/boehmite: A highly active catalyst for hydrogenolysis of glycerol to 1,2propanediol. Catal. Commun. 2013, 32, 52-57. [CrossRef]

179. Lee, M.; Hwang, Y.K.; Chang, J.S.; Chae, H.J.; Hwang, D.W. Vapor-phase hydrogenolysis of glycerol to 1,2-propanediol using a chromium-free $\mathrm{Ni}-\mathrm{Cu}-\mathrm{SiO}_{2}$ nanocomposite catalyst. Catal. Commun. 2016, 84, 5-10. [CrossRef]

180. Salazar, J.B.; Falcone, D.D.; Pham, H.N.; Datye, A.K.; Passos, F.B.; Davis, R.J. Selective production of 1,2-propanediol by hydrogenolysis of glycerol over bimetallic Ru-Cu nanoparticles supported on $\mathrm{TiO}_{2}$. Appl. Catal. A Gen. 2014, 482, 137-144. [CrossRef]

181. Poddar, M.K.; Pandey, A.; Jha, M.K.; Andola, S.C.; Ali, S.S.; Bhandari, S.; Sahani, G.K.; Bal, R. Aqueous phase hydrogenolysis of renewable glycerol to 1, 2-propanediol over bimetallic highly stable and efficient $\mathrm{Ni}-\mathrm{Cu} / \mathrm{Al}_{2} \mathrm{O}_{3}$ catalyst. Mol. Catal. 2021, 515, 111943. [CrossRef]

182. Azri, N.; Ramli, I.; Nda-Umar, U.I.; Shamsuddin, M.R.; Saiman, M.I.; Taufiq-Yap, Y.H. Copper-dolomite as effective catalyst for glycerol hydrogenolysis to 1,2-propanediol. J. Taiwan Inst. Chem. Eng. 2020, 112, 34-51. [CrossRef]

183. Montassier, C.; Giraud, D.; Barbier, J. Polyol Conversion by Liquid Phase Heterogeneous Catalysis over Metals; Elsevier: Amsterdam, The Netherlands, 1988; Volume 41.

184. Kang, Y.; Bu, X.; Wang, G.; Wang, X.; Li, Q.; Feng, Y. A highly active $\mathrm{Cu}-\mathrm{Pt} / \mathrm{SiO}_{2}$ bimetal for the hydrogenolysis of glycerol to 1,2-propanediol. Catal. Lett. 2016, 146, 1408-1414. [CrossRef]

185. Von Held Soares, A.; Atia, H.; Armbruster, U.; Passos, F.B.; Martin, A. Platinum, palladium and nickel supported on Fe $\mathrm{O}_{4}$ as catalysts for glycerol aqueous-phase hydrogenolysis and reforming. Appl. Catal. A Gen. 2017, 548, 179-190. [CrossRef]

186. Gogoi, P.; Chilukuri, S.; Thirumalaiswamy, R. An active K-OMS-2 supported catalyst for hydrogenolysis of glycerol. ChemistrySelect 2021, 6, 8700-8708. [CrossRef]

187. Azri, N.; Irmawati, R.; Nda-Umar, U.I.; Saiman, M.I.; Taufiq-Yap, Y.H. Effect of different supports for copper as catalysts on glycerol hydrogenolysis to 1,2-propanediol. J. King Saud Univ. Sci. 2021, 33, 101417. [CrossRef]

188. Dias, A.P.; Fonseca, F.G.; Catarino, M.; Gomes, J. Biodiesel glycerin valorization into oxygenated fuel additives. Catal. Lett. 2021. [CrossRef]

189. Ahmed, T.S.; Abdelaziz, O.Y.; Roberts, G.W. Preparation of $\mathrm{Al}_{2} \mathrm{O}_{3} / \mathrm{AlF}_{3}$-supported ruthenium catalysts for the hydrogenolysis of biodiesel-derived crude glycerol. Ind. Eng. Chem. Res. 2016, 55, 5536-5544. [CrossRef] 
190. Ross, J.R.H. Catalyst preparation. In Contemporary Catalysis; Elsevier: Amsterdam, The Netherlands, 2019; pp. 91-120. [CrossRef]

191. Hutchings, G.J.; Védrine, J.C. Heterogenous catalyst preparation. In Basic Principles in Applied Catalysis; Springer: Cham, Switzerland, 2004; pp. 215-258. [CrossRef]

192. Vivian, A.; Soumoy, L.; Fusaro, L.; Louette, P.; Felten, A.; Fiorilli, S.; Debecker, D.P.; Aprile, C. The high activity of mesoporous $\mathrm{Ga}_{\mathrm{SiO}}$ catalysts in the upgrading of glycerol to solketal explained by in-depth characterization. J. Catal. 2021, 400, 83-92. [CrossRef]

193. Abdullah, R.; Saleh, S.N.M.; Embong, K.; Abdullah, A.Z. Recent developments and potential advancement in the kinetics of catalytic oxidation of glycerol. Chem. Eng. Commun. 2019, 1298-1328. [CrossRef]

194. Vasiliadou, E.S.; Lemonidou, A.A. Glycerol transformation to value added $C_{3}$ diols: Reaction mechanism, kinetic, and engineering aspects. Wiley Interdiscip. Rev. Energy Environ. 2015, 4, 486-520. [CrossRef]

195. Wang, S.; Yang, X.; Xu, S.; Li, B. Investigation into enhancing reforming of biomass-derived glycerol in a membrane reactor with hydrogen separation. Fuel Process. Technol. 2018, 178, 283-292. [CrossRef] 